\title{
Challenges of Microgrids in Remote Communities: A STEEP Model Application
}

\author{
Daniel Akinyele ${ }^{1,2, *(\mathbb{D})}$, Juri Belikov ${ }^{3}$ (i) and Yoash Levron ${ }^{1}$ \\ 1 Andrew and Erna Viterbi Faculty of Electrical Engineering, Technion-Israel Institute of Technology, \\ Haifa 3200003, Israel; yoashl@ee.technion.ac.il \\ 2 Department of Electrical and Computer Engineering, Elizade University, P. M. B 002 Ilara-Mokin, \\ Ondo State, Nigeria \\ 3 Department of Computer Systems, Tallinn University of Technology, Akadeemia tee 15a, \\ 12618 Tallinn, Estonia; juri.belikov@ttu.ee \\ * Correspondence: daniel.akinyele@elizadeuniversity.edu.ng; Tel.: +972-48293231
}

Received: 15 January 2018; Accepted: 25 January 2018; Published: 14 February 2018

\begin{abstract}
There is a growing interest in the application of microgrids around the world because of their potential for achieving a flexible, reliable, efficient and smart electrical grid system and supplying energy to off-grid communities, including their economic benefits. Several research studies have examined the application issues of microgrids. However, a lack of in-depth considerations for the enabling planning conditions has been identified as a major reason why microgrids fail in several off-grid communities. This development requires research efforts that consider better strategies and framework for sustainable microgrids in remote communities. This paper first presents a comprehensive review of microgrid technologies and their applications. It then proposes the STEEP model to examine critically the failure factors based on the social, technical, economic, environmental and policy (STEEP) perspectives. The model details the key dimensions and actions necessary for addressing the challenge of microgrid failure in remote communities. The study uses remote communities within Nigeria, West Africa, as case studies and demonstrates the need for the STEEP approach for better understanding of microgrid planning and development. Better insights into microgrid systems are expected to address the drawbacks and improve the situation that can lead to widespread and sustainable applications in off-grid communities around the world in the future. The paper introduces the sustainable planning framework (SPF) based on the STEEP model, which can form a general basis for planning microgrids in any remote location.
\end{abstract}

Keywords: energy planning; energy demand; renewable energy; microgrid; systems failure; sustainability

\section{Introduction}

There is a growing interest in the application of microgrids around the world because of their potential for achieving a flexible, reliable, efficient and smart electrical grid system and supplying energy to off-grid communities, including their economic benefits [1]. These attributes and the advocacy for low-carbon future by policy-makers, governments, developers, independent producers, industrialists and other concerned stakeholders, present microgrids as a promising electricity generation option now and in the future.

Currently, about 1.3 billion people out of the total population of 7 billion do not have access to modern energy supply [2]. The International Energy Association (IEA) reported that about 622 million people out of the 1.3 billion population do not have access to electricity in Africa [3]. While 621 million people out of the 1.3 billion population are from Sub-Saharan Africa, only approximately 1 million people are from Africa's Northern region [4]. The energy report further reveals that the Sub-Saharan Africa has the lowest electrification access rate in the world. For instance, more than $60 \%$ of Nigeria's 
citizens do not have access to its national grid [5]. It is against this backdrop that the governments within the Sub-Saharan Africa region are considering increasing energy access rate as one of the important programmes on their agenda. Their aim is to achieve this feat through the deployments of microgrids, especially those that are based on renewable energy resources, e.g., solar, wind, biomass and hydropower.

Microgrids have been a key topic over the past decade, and have triggered credible research interests and efforts toward advancing the energy knowledge, by addressing different kinds of challenges such as peak demand, power quality, increased carbon emissions, reliability, resiliency, islanding, variable energy generation, control, microgrid integration, bi-directional power flow $[6,7]$. It is of interest in this paper to first provide a survey of the existing contributions both on reviews and applications studies to establish a relevant background for this current paper.

A review of modeling, control, protection, simulation and future potential of microgrids has been published, focusing on the technical issues associated with frequency control and re-synchronization as related to typical distributed energy sources (DERs) for functional utility operations [6]. A paper on the survey of techniques for managing microgrids has been published, with focus on system design and control for reliable and economic energy supply [7]. A review has been presented on the distributed generation and microgrids for small island electrification, with a focus on maximum utilization of renewable energy resources in developing countries, particularly India [8]. The autonomous control of microgrids has been discussed, with emphasis on the coordination of operation of different participating microgrids both for on-grid and islanded mode [9].

The technical challenges on microgrids have been presented, focusing on the control of operation of a number of microgrid systems within an electrical area [10], while a study on the centralised control for optimizing microgrids operation has also been discussed with emphasis on the strategies for the interconnection of microgrids with the power grid [11]. The review of power-sharing control strategies for islanding operation of A-C microgrid systems has been discussed categorising various approaches for power sharing between the participating microgrids [12]. A critical review of the best practices on microgrids for rural electrification has been presented focusing on seven different case studies advocating for adequately financed renewable energy-based microgrids as a possible solution to the identified energy poverty situation in remote communities [13].

The review of techno-economic challenges for implementing rural microgrids has been presented using South Africa as a case study, mentioning reliability as the main challenge of the off-grid microgrids [14], while an overview of the real-world microgrids has been presented discussing the hardware and control options for microgrid operation [15]. A study has been conducted on protection principles for future microgrids with emphasis on the protection issues of low-voltage microgrids and the possible solutions [16]. A review of the primary-control techniques for the islanded microgrids has been discussed assessing the most up-to-date primary control techniques for an autonomous operation of the microgrids such as the droop-based and non-droop-based power-sharing approaches [17]. The techno-economic and life cycle performance analyses of a photovoltaic microgrid have been discussed, focusing on simulation and analysis of energy supply system for remote communities [18].

A review of the potential of renewable energy sources has been discussed with emphasis on distributed power generation in Nigeria and how the energy system could be used to address the energy shortage challenge in the country [19]. The review of hybrid energy storage systems for renewable energy sources has been conducted, which focuses on the application of microgrids [20]. A study on the controls for microgrids with energy storage has been discussed, focusing on the review, challenges and the research needs [21]. A technical review of the critical role of microgrids in transition to a smarter grid has been presented, which emphasises the control of multiple microgrid systems in the electrical network [22]. The state-of-the-art in research on microgrids has also been discussed presenting the progress in microgrid technologies for electricity generation, while a literature review of the value streams in microgrids has been presented [23,24]. 
The review of the coordination strategies and protection schemes for microgrid systems has been discussed focussing on how the challenge of bi-directional power flow as a result of the operation of clusters of microgrids in the network can be addressed [25]. The review of active and reactive power sharing strategies has been conducted concentrating on the hierarchically controlled microgrids in a power network [26]. The review and classification of topologies of the hybrid AC/DC microgrids has been discussed with a focus on the interconnection of the different networks and the conventional grid [27], while an overview of the AC and DC microgrid technologies has also been presented detailing the elements and issues involved in the implementation and development, viz. protections, power converters, economic analysis, and availability [28].

A review of the optimisation approaches in microgrids with hybrid energy systems arrangement has been discussed presenting the concept of hybrid renewable energy systems (HRES) and the state-of-art application of optimization tools and techniques to microgrids and integrating renewable energy systems with storage [29]. A study has been conducted on microgrids as the power systems for the 21st century, focusing on the major applications of the microgrid technologies [30], while an overview of the microgrid paradigm has also been discussed [31]. A study on rural microgrids and its potential application has been published, using Colombia as a case study; it analyses the possibility of using the systems as a solution to the energy access problem in isolated areas [32]. A literature review of microgrids has also been discussed [33]. A review of recent developments in microgrids has been presented with example cases around the world [34].

A review of power electronics-based microgrids has been presented discussing the microgrid configurations and the possible structure options and control methods of DER units [35], while a comprehensive review of power quality improvement in autonomous microgrids has also been discussed emphasising the application of multi-functional voltage source inverters [36]. The research on some aspects of stability in microgrids has been published focusing on the stability aspects of remote, utility-connected and facility microgrids, and the modes of operation, control topology, types of micro sources and the network parameters [37]. The analysis of photovoltaic mini-grid systems for remote locations in a developing country has been presented, using the techno-economic evaluation approach [38]. A review of the protection challenges in microgrid systems has been discussed presenting the protection problems resulting from microgrid's application in distribution power system and the classification of the protection schemes [39].

While efforts are continually being made by several developing countries toward increasing the energy access rate, there is a lack of considerations for the enabling planning factors, which is why microgrids fail in several off-grid communities. This prevailing challenge requires research efforts that consider new ways of thinking, better and effective strategies and framework that can help achieve sustainable microgrids in remote communities.

The aforementioned existing studies have provided a relevant and worthwhile background for advancing the knowledge in the microgrid research field, with contributions in different directions. Some of the papers have presented the overview of microgrid systems [8,13-15,20,22-24,27,28,33,34] focusing on the various technologies and recent developments and their potential application for rural electrification and islanded purposes; a review of renewable energy resources for microgrid application was also presented [19]. Some other papers have focused on the review of control strategies of microgrid and autonomous applications with the aim of achieving proper and effective coordination of a cluster of microgrids in electrical systems for optimal operation $[6,7,9,11,12,17,21,25,26]$. In addition, some of the studies presented the review of protection challenges and principles relating to microgrid systems $[10,16,25,35,39]$, while the contributions on the techno-economic and impact analysis and application of rural microgrids were made in $[18,32,38]$. A review of classification of topologies of hybrid microgrids, classification of topologies and optimal considerations were achieved in [20,27,29], while the remaining contributions are based on the concept, stability and power quality issues of autonomous microgrid systems [30,31,36,37]. 
However, developing a strategic planning approach for addressing microgrid failure in several remote communities in developing countries, remains a gap that requires research attention. This current paper examines the microgrid issues from this perspective, which is different from the research directions presented by the aforementioned studies [6-39]. It identifies the current challenge being experienced in Nigeria that is affecting the proliferation of grid-independent microgrid systems, even though there are promising renewable energy resources in the country. The higher system failure rates in Nigeria, for example, strengthens the view among the concerned stakeholders-the energy users, investors or clients that solar microgrids are not appropriate for the country's market [40]. Such a view is of great concern as it is not healthy for the future of renewable energy technologies in the country.

Therefore, this paper first presents a comprehensive review of the microgrid technologies, status, and applications such as the solar PV, wind, biomass, small hydro, microturbine, reciprocating internal combustion engines and the fuel cells. It then attempts to address the identified problem by proposing the STEEP model based on the enabling factors such as social (S), technical $(\mathrm{T})$, economic (E), environmental (E) and policy (P) perspectives. This model is derived from the fundamental sustainability principle [41-45], the authors' practical experience, best practices and the background knowledge of microgrid concept. The model intends to provide insights into the necessary approaches and actions for achieving sustainable microgrids in remote communities. Therefore, the STEEP model may be defined as a multidimensional perspective for conceptualizing, analyzing, planning and managing localized energy systems.

The uniqueness of this study is that it presents a critical analysis of the challenges of microgrid systems in remote communities by carefully considering the prevailing situation and the local conditions; moreover, it systematically details both the microgrid failure factors (MFFs) and the sustainable microgrid factors (SMFs) by using the STEEP framework. Therefore, the proposed STEEP approach focuses on the prevailing issues that decision-makers, energy designers and developers, researchers and every other concerned stakeholder should address to ensure sustainable adoption and planning of microgrids. The paper uses remote communities in Nigeria, as case studies and its proposed contributions are expected to answer the pertinent question of why microgrids fail and address the problem and critical gap, by providing a better way of understanding microgrid planning and development.

Better insights into how the microgrid models work become necessary to address the drawbacks and improve the situation, which can lead to widespread and sustainable microgrid applications in off-grid communities around the world in the future. Considering this, the paper introduces sustainable microgrid framework (SPF) that can serve as a general basis for planning microgrids in any location. The study demonstrates that addressing the grand challenge (i.e., system failure) in the absence of any of the five elements of the STEEP model means an incomplete solution. This is because all the dimensions need to work together to overcome the barrier and achieve the desired sustainable energy development, which is beyond the traditional techno-economic planning perspective. For example, the lack of education affects the people's way of using energy. It also affects the way they dispose dangerous materials such as the compact fluorescent tubes (CFLs), lead-acid battery etc., after their useful life. This scenario presents how the lack of education, which is a social problem can affect the technical and the environmental factors. Though the environmental aspect is not a direct cause of system failure in the context of this study, it has been carefully considered as a vital ingredient of sustainability. Its relevance is presented in terms of microgrid planning, development and sustainability. Importantly, an in-depth understanding of the situation and local conditions are necessary for planning, implementing and managing microgrid systems.

The remaining aspects of the paper is arranged as follows: Section 2 focuses on the different microgrid technologies; Section 3 presents the background-current situation, local issues and the proposed model; Section 4 discusses the microgrid failure factors (MFFs); Section 5 presents the 
sustainable microgrid factors (SMFs), while Section 6 focuses on the sustainable planning framework $(\mathrm{SPF})$ and the prospects of microgrids in remote communities; Section 7 concludes the paper.

\section{Microgrid Technologies}

Microgrids have been defined in various ways, all of which present them as a smaller version of the electric power grid [46-53]. They are a localized arrangement of electrical sources and loads that operate in connection to the existing grid system, i.e., the on-grid mode, and can also operate as a stand-alone energy system when disconnected from the grid, i.e., off-grid mode.

However, one of the popular definitions of microgrids from the point of view of remote communities that this paper considers is that they are a small-scale electric power system designed to provide electricity for a small community [30]. Microgrids differ in sizes or capacities based on their scales such as mini, small, medium and large distributed generation (DG) technologies with capacities of 0.001-0.005 MW, 0.005-5 MW, 5-50 MW and 50-300 MW, respectively [54,55].

The lack of access to the national grid, remoteness of the locations and the economic considerations are among the major factors that justify the deployment of microgrids in off-grid communities [56-60]. Microgrid systems could be based on different kinds of energy resources, categorized as renewable and conventional sources [46], depending on the type of resource that is available at the location of interest. The microgrid technologies are summarized in Tables 1 and 2 based on their energy sources. The renewable energy includes solar, wind, hydro, biomass and geothermal, while the conventional energy sources include steam/gas turbines, micro-turbines, reciprocating internal combustion engines and low- and high-temperature fuel cells [46].

The information in Tables 1 and 2 also include the capacity, development and economic status, environmental impact, social motivation, actual deployment, different applications based on sectors, costs and the possibility for combined-heat and power (CHP) application.

However, because of the climate change and global warming issues that result in the aspirational target set by policy-makers to achieve sustainable energy future, the global community is strongly advocating the application of eco-friendly energy generation technologies [61-64]. This is one of the key factors that drive a growing interest in renewable energy-based electricity systems. Therefore, this paper focuses on the renewable energy-based microgrid systems, and it examines why such systems fail in remote communities using Nigeria as a case study.

A brief introduction of the common potential renewable energy resources for microgrid systems in Nigeria's remote communities is presented such as the solar, wind, biomass and hydro sources, including their basic working principles [65]. The country is located in West Africa, and it shares a border with Niger to the north, Benin to the west, Cameroon to the east, the Atlantic Ocean to the south, with Chad to the north-east [66]. It has a population of about 180 million and its abundant renewable energy resources are summarized in Table 3 [67-69]. 
Table 1. Summary of renewable energy-based microgrid technologies [1,46]. PV:photovoltaic; SHP:small hydropower; CHP:combined-heat and power.

\begin{tabular}{|c|c|c|c|c|c|c|c|}
\hline Technology & PV & SHP & $\begin{array}{l}\text { Wind } \\
\text { Onshore }\end{array}$ & $\begin{array}{l}\text { Wind } \\
\text { Offshore }\end{array}$ & Solar Thermal & Biomass & Geothermal \\
\hline Type of fuel & Solar & Water & Wind & Wind & Solar & Biomass & Earth \\
\hline Capacity (MW) & $<0.001-5$ & $0.05-1$ & $0.5-6+$ & $5-10+$ & $0.001-2$ & $0.001-5$ & $0.5-3+$ \\
\hline Development status & Developed/Commercial & $\begin{array}{l}\text { Developing/ } \\
\text { Commercial }\end{array}$ & Commercial & $\begin{array}{l}\text { Developing/ } \\
\text { Commercial }\end{array}$ & $\begin{array}{l}\text { Developing/ } \\
\text { Commercial/Demo }\end{array}$ & Developing & $\begin{array}{l}\text { Developing/ } \\
\text { Commercial/Demo }\end{array}$ \\
\hline Economic status & Expensive & Moderate & Moderate & Expensive & Moderate & Moderate & Expensive \\
\hline Environmental impact & Friendly & Friendly & Friendly & Friendly & Friendly & Friendly & Friendly \\
\hline Social motivation & High & High & High & High & High & Moderate & Medium \\
\hline Actual deployment & Small, rapidly increasing & Medium & Medium & $\begin{array}{l}\text { Small, rapidly } \\
\text { increasing }\end{array}$ & $\begin{array}{l}\text { Small, rapidly } \\
\text { increasing }\end{array}$ & $\begin{array}{l}\text { Small, rapidly } \\
\text { increasing }\end{array}$ & High \\
\hline Industrial application & Usable & Suggested & Suggested & Not suggested & Not suggested & Suggested & Not suggested \\
\hline Commercial application & Suggested & Usable & Usable & Not suggested & Not suggested & Suggested & Not suggested \\
\hline Household application & $\begin{array}{l}\text { Perfectly matched the } \\
\text { requirements of the sector }\end{array}$ & Not suggested & Not suggested & Not suggested & Not suggested & Suggested & Not suggested \\
\hline Capital cost $(€ / \mathrm{kW})$ & $4000-8000$ & $1400-5000$ & 800-2000 & $1200-3000$ & $1500-2000$ & $800-4000$ & \\
\hline Installation cost $(€ / \mathrm{kW})$ & $40-150$ & $100-200$ & $100-200$ & $600-800$ & $100-200$ & $200-400$ & \\
\hline Cost of energy $(€ / \mathrm{kWh})$ & $20-40$ & $6-14$ & $6-10$ & $8-15$ & - & - & - \\
\hline Lifespan (yrs) & $20-30$ & 60 & 20 & 20 & 20 & $20-30$ & 20 \\
\hline Possibility of CHP & Yes & No & No & No & Yes & Yes & Yes \\
\hline
\end{tabular}


Table 2. Summary of conventional energy-based microgrid technologies [46].

\begin{tabular}{|c|c|c|c|c|c|c|c|}
\hline Technology & $\begin{array}{l}\text { Small } \\
\text { Steam } \\
\text { Turbine }\end{array}$ & $\begin{array}{l}\text { Gas } \\
\text { Turbines }\end{array}$ & Micro-Turbines & $\begin{array}{l}\text { Reciprocating Internal } \\
\text { Combus-Tion Engines }\end{array}$ & Stirling Engines & $\begin{array}{l}\text { High-Temp Fuel } \\
\text { Cells }\end{array}$ & $\begin{array}{l}\text { Low-Temp Fuel } \\
\text { Cells }\end{array}$ \\
\hline Type of fuel & $\begin{array}{l}\text { Gas, coal, } \\
\text { biomass }\end{array}$ & Gas & Gas & Diesel, oil, biofuel, gas & Gas, solar & Gas, hydrogen & Gas, hydrogen \\
\hline Capacity (MW) & $0.5-10+$ & $0.5-10+$ & $0.03-0.5$ & $0.5-10+$ & $<0.01-1+$ & $1-10+$ & $<0.1-3+$ \\
\hline Development Status & Commercial & Commercial & $\begin{array}{l}\text { Developing/ } \\
\text { Commercial }\end{array}$ & $\begin{array}{l}\text { Developing/Demo/ } \\
\text { Commercial }\end{array}$ & $\begin{array}{l}\text { Developing/ } \\
\text { Commercial }\end{array}$ & $\begin{array}{l}\text { Developing/ } \\
\text { Commercial }\end{array}$ & Commercial \\
\hline Economic status & Cheap & Cheap & Moderate & Cheap & $\begin{array}{l}\text { Expensive/ } \\
\text { Moderate }\end{array}$ & Expensive & Expensive \\
\hline Environmental impact & $\begin{array}{l}\text { Significant/ } \\
\text { Moderate }\end{array}$ & Significant & Moderate & Significant/Friendly & $\begin{array}{l}\text { Moderate/ } \\
\text { Friendly }\end{array}$ & Moderate & Moderate \\
\hline Social motivation & Low & Medium & Medium & Low & Medium/High & High & High \\
\hline Actual deployment & High & High & $\begin{array}{l}\text { Small, rapidly } \\
\text { increasing }\end{array}$ & High & Small & Small & Small, increasing \\
\hline Industrial application & $\begin{array}{l}\text { Considered } \\
\text { for the sector }\end{array}$ & $\begin{array}{l}\text { Considered } \\
\text { for the sector }\end{array}$ & Usable & $\begin{array}{l}\text { Considered for the } \\
\text { sector/Suggested }\end{array}$ & Usable & $\begin{array}{l}\text { Considered for the } \\
\text { sector/Suggested }\end{array}$ & \\
\hline Commercial application & Usable & Suggested & Suggested & $\begin{array}{l}\text { Considered for the } \\
\text { sector/Suggested }\end{array}$ & $\begin{array}{l}\text { Considered for the } \\
\text { sector/Suggested }\end{array}$ & Usable & $\begin{array}{l}\text { Considered for the } \\
\text { sector/Suggested }\end{array}$ \\
\hline Household application & $\begin{array}{l}\text { Not } \\
\text { suggested }\end{array}$ & $\begin{array}{l}\text { Not } \\
\text { suggested }\end{array}$ & $\begin{array}{l}\text { Considered for the } \\
\text { sector/Suggested }\end{array}$ & Suggested & $\begin{array}{l}\text { Considered for the } \\
\text { sector }\end{array}$ & Not suggested & $\begin{array}{l}\text { Considered for the } \\
\text { sector }\end{array}$ \\
\hline Capital cost $(€ / \mathrm{kW})$ & $550-1250$ & $500-1100$ & $1000-2000$ & $350-1000$ & $1500-8000$ & $3500-10,000$ & $2000-8000$ \\
\hline Installation cost $(€ / \mathrm{kW})$ & $100-200$ & $65-150$ & 50-200 & $60-120$ & $40-200$ & $500-850$ & $500-850$ \\
\hline Cost of energy $(€ / \mathrm{kWh})$ & $3-7$ & $3-5$ & $8-15$ & $4-7$ & $9-15$ & $15-35$ & $10-25$ \\
\hline Lifespan (yrs) & 20 & 20 & 20 & 20 & 15 & 10 & 10 \\
\hline Possibility of CHP & Yes & Yes & Yes & Yes & Yes & Yes & Yes \\
\hline
\end{tabular}


Table 3. Renewable energy potential in Nigeria.

\begin{tabular}{lll}
\hline Technology & Capacity/Potential & Value/Units \\
\hline Estimated capacity of small hydro & 3500 & $\mathrm{MW}$ \\
Estimated large hydro & 11,250 & $\mathrm{MW}$ \\
Wind & $2.0-4.0$ & $\mathrm{~m} / \mathrm{s}$ at a 10-m height \\
Solar irradiation & $3.0-7.0$ & $\mathrm{kWh} / \mathrm{m}^{2} / \mathrm{d}$ \\
Energy crops & $28.2(\sim 30 \%$ of total land $)$ & million hectares of arable land \\
Agro-waste & 11.24 tonnes & calorific value of $\sim 148,000 \mathrm{MJ}$ \\
Fuel wood & 39.1 tonnes & calorific value of 531,000 MJ \\
Animal waste & $\sim 285$ & million tons/yr of production \\
Saw dust & 1.8 tonnes & calorific value of 31,430 MJ \\
Municipal solid waste & 4.075 & \\
Wave and tidal energy & 150,000 & TJ \\
\hline
\end{tabular}

\subsection{Solar}

The solar energy resource is harnessed by converting the sunlight to DC supply through the use of solar photovoltaic cell or module [70,71]. Basically, a solar PV microgrid is made up of the PV and non-PV parts. The PV part consists of the modules or arrays, while the non-PV part, usually called the balance-of-system (BOS) includes the battery, inverter/controller, cabling, protective devices and the frames [72-75]. Nigeria's location and its solar energy potential ranging from 3.5 to $7.0 \mathrm{kWh} / \mathrm{m}^{2} / \mathrm{d}$ are favorable to solar photovoltaic microgrid that can be used as part of the solutions to its energy shortage challenge.

There are different kinds of PV technologies such as the monocrystalline (m-Si), polycrystalline (p-Si), thin films-amorphous silicon (a-Si), cadmium telluride (CdTe), copper indium gallium selenide (CIGS) and the new generation technologies - organic photovoltaics [76-79]. The location's environmental characteristic is one among the important criteria for the selection and application of the PV technologies in microgrids [80]. The commonly used PV technology in Nigeria is the crystalline silicon type, e.g., $\mathrm{m}-\mathrm{Si} / \mathrm{p}$-Si. The power output of a solar microgrid system can be estimated as [81-84]

$$
P_{o}=P_{M} D_{r f} n_{M}\left(1+\beta\left(T_{M}-T_{M, S T C}\right)\right) \frac{G_{L}}{G_{S T C}},
$$

such that

$$
T_{M}=T_{A}+\left(N O C T-20^{\circ} \mathrm{C}\right) \frac{G_{L}}{G_{R}},
$$

where $P_{M}, D_{r f}, n_{M}, \beta, T_{M}, T_{M, S T C}, G_{L}, G_{S T C}, G_{R}, T_{A}$, and NOCT are the solar module's rated power, derating factor, number of modules, temperature coefficient of power, module temperature, module temperature at standard test conditions (STC), location's solar irradiance, solar irradiance at STC, reference solar irradiance, ambient temperature, and the nominal operating cell temperature, respectively. The solar irradiance at STC, reference solar irradiance, and the NOCT are $1000 \mathrm{~W} / \mathrm{m}^{2}$, $800 \mathrm{~W} / \mathrm{m}^{2}$ and $45 \pm 2{ }^{\circ} \mathrm{C}$, respectively $[18,77,81]$. The solar irradiance and the ambient temperature are two major factors that affect the performance of the solar PV microgrids, others are dust, incomplete solar radiation absorption, aging, and wiring losses [79].

Examples of solar PV microgrids are presented in Figure 1, with battery banks and inverter controllers stationed indoor. The 4.4 and $4.2 \mathrm{~kW}$ solar microgrids were installed by the National Agency for Science and Engineering Infrastructure (NASENI), Abuja, Nigeria, on behalf of the National Information Technology Development Agency (NITDA), Abuja, Nigeria, for the Rural Information Technology Centers in different parts of the country $[76,85]$.

There are several other solar PV systems in the country (both in the south and the north), which have been deployed for different purposes such as street lighting, community water-pumping, energy supply to community halls, households, schools and health centers. The PV microgrid system is the most popular and commonly used microgrid systems in the country. 


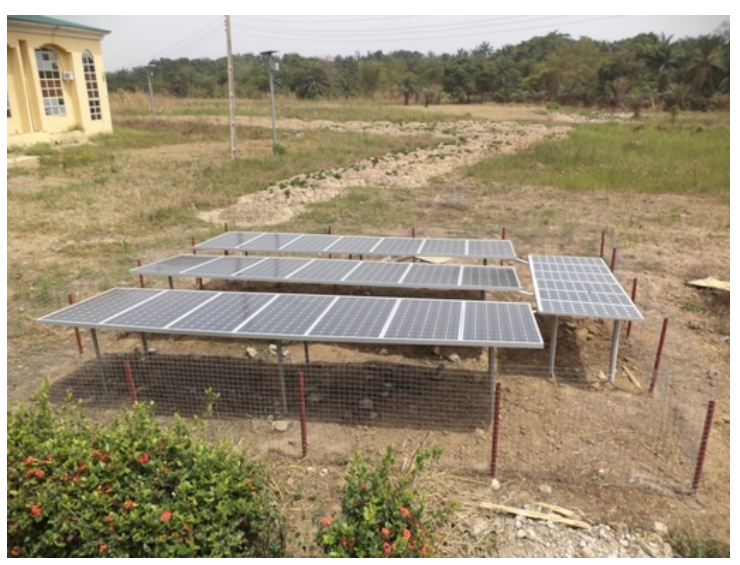

(a)

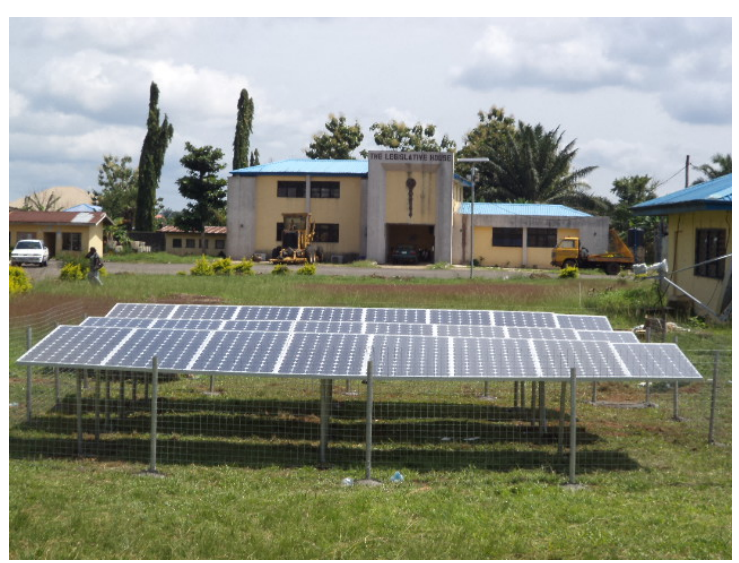

(b)

Figure 1. Examples of solar photovoltaic (PV) microgrids with battery banks and inverter controllers. (a) $4.4 \mathrm{~kW}$ solar microgrid for Aninri Local Government; (b) $4.2 \mathrm{~kW}$ solar microgrid for Atakumosa Local Government.

\subsection{Wind}

Nigeria's wind resource is categorized into four regimes such as $>4.0 \mathrm{~m} / \mathrm{s}, 3.1-4.0 \mathrm{~m} / \mathrm{s}, 2.1-3.0 \mathrm{~m} / \mathrm{s}$ and $1.0-2.0 \mathrm{~m} / \mathrm{s}$ [59]. Wind speeds are generally weak in the southern part of the country, compared to the northern region, except for the coastal regions and offshore areas. It has been observed through research studies that wind energy is strongest in the hilly regions of the country's northern region, and the mountainous areas of the north-central, south-eastern, and of course, the offshore areas [86-93]. Such findings indicate that wind energy-based microgrids are a promising option for the specified locations.

However, the application of wind energy is limited in the country. Only a few off-grid wind power systems were installed about 6 decades ago in five states within the country's northern region, designed to pump water, including a $5 \mathrm{~kW}$ wind energy conversion system installed for village electrification at Sayyan Gidan Gada, Sokoto State [59]. The wind system installation is not as widespread as solar PV system. Another practical challenge is the lack or absence of wind turbine blades that can match the wind terrain of some specific locations. Several imported wind turbine blades do not work in Nigeria because of the mismatch in the wind regime. This development is largely due to a lack of expertise in wind power system in the country. A good technical knowledge and understanding of a location's wind energy resource is key to selecting the appropriate wind turbine systems. Building a local capacity in distributed wind power system is expected to address this problem in the future.

The power output delivered by a wind-based microgrid at a particular wind speed can be estimated as [42,94-97]

$$
P_{w}=\frac{1}{2} C_{p} \rho A V^{3},
$$

where $C_{p}, \rho, A$, and $V$ represent maximum power coefficient, air density $\left(\mathrm{kg} / \mathrm{m}^{3}\right)$, the swept area by the wind turbine blades and the wind speed, respectively. The area, $A$ is given by $\pi R^{2}$, where $R$ is the radius of the turbine's rotor.

The power coefficient is obtained when the power extracted by the turbine is divided by the power available in the wind energy, with typical values ranging from 25 to $45 \%$; a maximum theoretical value is $59.3 \%$, which is usually referred to as the Bertz limit [98]. Equation (3) demonstrates that a small increase in wind speeds can lead to a large wind power output. The wind turbine rotor size also affects the value of $A$ and $V$. In addition, it is also found that wind speeds increase with height, 
which affects the amount of electricity produced by the turbine. The wind speed at a given hub height can be calculated as $[99,100]$

$$
V=V_{r f}\left(\frac{h}{h_{r f}}\right)^{\alpha},
$$

where $V$ and $V_{r f}$ represent the wind speed at the hub height, $h$ and the wind speed $(\mathrm{m} / \mathrm{s})$ at a reference $h e i g h t, h_{r f}$, while $\alpha$ is the coefficient of ground surface friction, with a typical value of $<0.1$ and $>0.25$ for water/ice of largely forested terrains [94].

An example of a wind-based microgrid is shown in Figure 2. The system was installed at an off-grid house in Brooklyn, Wellington, New Zealand [94]. Because wind energy resource is highly intermittent, the microgrid system is designed as a hybrid configuration of wind, solar and petrol resources. The microgrid system is made up of $2.5 \mathrm{~kW}$ wind turbine, $1 \mathrm{~kW}$ solar PV, $5.5 \mathrm{kVA}$ generator and $1350 \mathrm{Ah}, 24 \mathrm{~V}$ battery bank for an average daily demand of $10 \mathrm{kWh}$. Though this off-grid system is not installed in Nigeria, it is used in this study for illustration and a suggestion of its possibility in the country in the future.

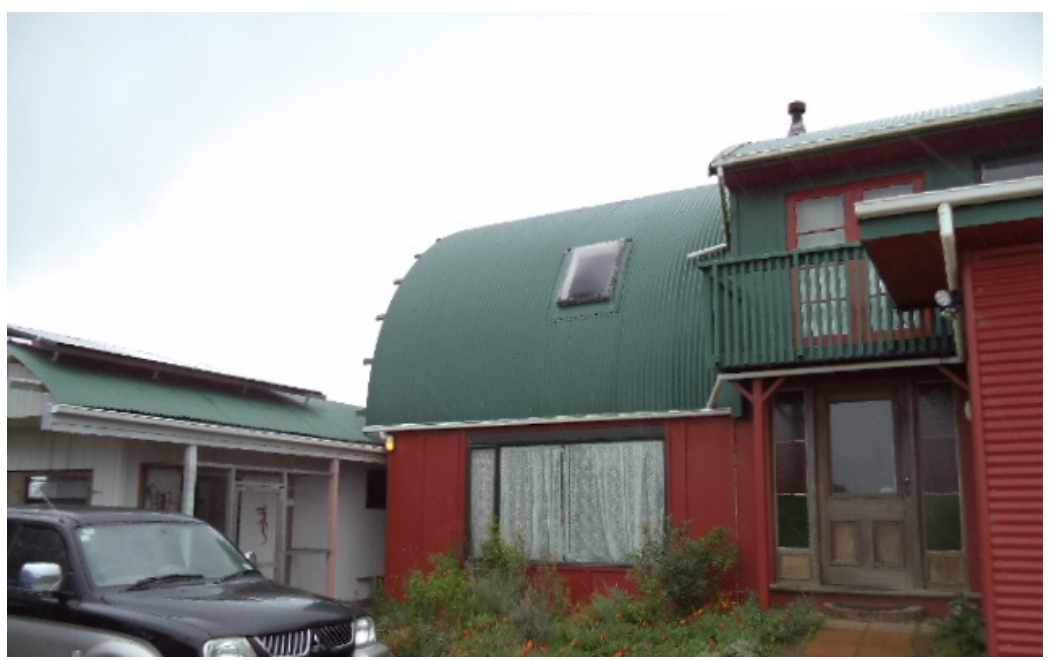

(a)

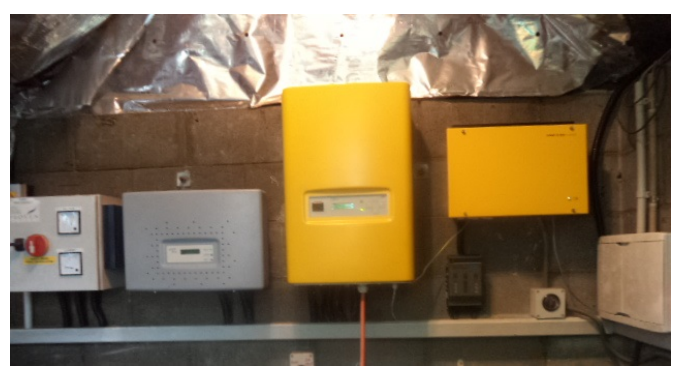

(c)

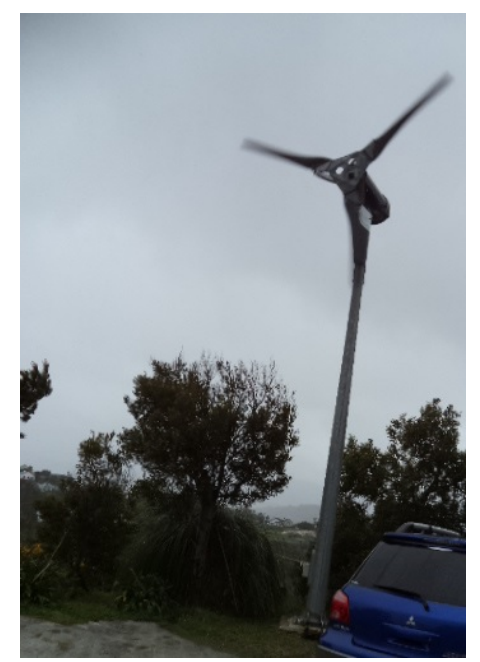

(b)

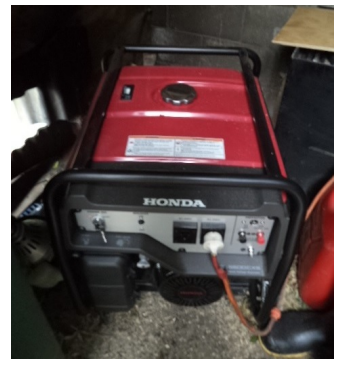

(e)

Figure 2. An example of a wind-based microgrid deployed for an off-grid house in Brooklyn, Wellington, New Zealand. (a) PV system on the roof of a house; (b) Wind turbine; (c) Rectifier, controllers and distribution board; (d) Battery bank; (e) Generator.

\subsection{Biomass}

The word biomass may be described as the energy that is obtainable from biological materials such as wood and food/animal wastes $[59,101]$. Nigeria's biomass resources include wood, sawdust, energy crops-Jatropha, sugarcane, maize, and animal waste, forage grasses and shrubs, municipal and industrial wastes. The motivation for the biomass option is derived from the possibility of 
transforming the agricultural materials into cleaner fuels such as briquettes, biogas, and biodiesel. The microgrid system based on biomass resources produce electricity either through a combustion or anaerobic digestion process [102-104].

There are two major elements when discussing the use of biomass as a fuel, and these are the calorific value, usually referred to as the energy content, and the moisture content [105]. The calorific value of a fuel or biomass is measured as its available or stored energy in Joules $(\mathrm{J})$ per unit volume $\left(\mathrm{m}^{3}\right)$ or mass $(\mathrm{kg})$. However, the useful quantity of energy in biomass or a fuel will be affected by the moisture content or the amount of water in the fuel. Moisture reduces the fuel's useful energy because it adds no value to it, which is why wood is processed to dry up its water content, usually through an oven-drying process. The heat or energy produced can be used for electricity generation through a thermodynamic process, and can also be used for CHP. The calorific or heating value of a dry wood chip, for instance, can be estimated as [105-107]

$$
Q_{H V}=\left(Q_{C H}-0.218 H_{C}\right) \frac{100-M_{C}}{100}-0.02442 M_{C}
$$

where $Q_{H V}, Q_{C H}, H_{C}$, and $M_{C}$ are heating value of wood chips $(\mathrm{GJ} / \mathrm{t})$, combustion heat of dry matter $(\mathrm{GJ} / \mathrm{t})$, the hydrogen content in dry matter $(\%)$, and moisture content $(\%)$, respectively.

The country has abundant biomass resources that certainly will be suitable for microgrid applications for remote communities, however, the government's effort to promote biomass utilization is currently limited to the transportation sector of the economy [59,108-112]. The 2017 bio-ethanol policy gives rise to $10 \%$ ethanol in the country's petroleum mix [59]. Since the feedstock for bio-ethanol is renewable, its potential application for electricity production purpose is promising for the country.

\subsection{Hydropower}

Generally, the hydropower or water power system generates electricity by allowing the water stored in a reservoir at a particular height, usually called the head, to fall on water turbines, thus, spinning it to drive an electric generator [113-116]. Nigeria has huge hydro resources because of its large and small rivers and streams in different parts of the country. While a large hydro system uses dams or reservoirs, a small hydropower (SHP) uses a run-of-river channel that does not require a dam [117]. The power and the energy output of a hydropower system can be estimated as $[117,118]$

$$
\begin{aligned}
& P=\eta_{h e} \rho g Q H, \\
& E=\eta_{h e} \rho g Q H \Delta t,
\end{aligned}
$$

where $\eta_{h e}, \rho, g, Q, H$, and $\Delta t$ represent hydraulic efficiency, water density $\left(\mathrm{kg} / \mathrm{m}^{3}\right)$, the acceleration due to gravity $\left(\mathrm{m} / \mathrm{s}^{2}\right)$, water flow $\left(\mathrm{m}^{3} / \mathrm{s}\right)$, head $(\mathrm{m})$ and interval of time (h), respectively. Equation (6) demonstrates that the higher the water flow and the head, the higher the value of the output power. Therefore, a location with a good water resource and a suitable head will favor a hydroelectricity system.

Water power currently accounts for approximately $32 \%$ of the country's installed centralized generation [59]. The total hydro resources that could be harnessed in the country was estimated as $11,250 \mathrm{MW}$ with an expected yearly electricity production of $36,000 \mathrm{GWh}[59,67]$. Based on the mentioned resources, water-based microgrids, e.g., small hydropower (SHP) systems are a promising option for rural electrification for the country. Such energy solutions also have a lower environmental impact compared to the centralized hydro systems that may cause displacements and affect topography as a large land mass is usually required [113].

Solar energy has been identified as a promising renewable energy resource in Nigeria, $[19,40,119]$, which is expected to thrive in the future as there is an increasing demand for off-grid rural electrification systems. 


\section{Current Situation, Local Issues and the Proposed Model}

\subsection{Background on Nigeria's Energy Situation and Issues}

Nigeria's centralized generation installed capacity is about $10 \mathrm{GW}$ but the available capacity is less than $5 \mathrm{GW}$ for some years $[85,120,121]$, fueled by about $70 \%$ fossil and $30 \%$ hydro resources. However, the country's Ministry of Power presented an available generation capacity of $>6$ GW in 2017 [122], which is still not adequate for the users' demand. Out of the country's population of about 180 million, only about $40 \%$ of its citizens have access to electricity and the actual electricity demand in the country is estimated at $10 \mathrm{GW}[60,65,121,123-125]$.

In addition, $6 \%$ of the $40 \%$ people that have access to the national grid are using petrol/diesel generators as supplements, while about $5 \%$ totally depend on generators to forestall the distress that erratic grid power supply may have on their businesses [85]. In fact, several organizations and businesses use costly generators as a back-up power supply during outages; a similar situation occurs to several homes that use conventional generators to meet a part of their energy demand [121]. The $60 \%$ of the country's population that does not have access to electricity combines mostly the rural and the peri-urban/semi-urban population.

The country's rural electrification programme is ineffective as approximately $>98 \%$ of the rural residents still do not have access to electricity, while the centralised power infrastructure suffers from poor maintenance, natural gas supply shortages, and old transmission and distribution network equipment [126-128]. Some of the government's programmes/policies are summarized in Table 4.

The high proportion of fossil fuel sources in the country's electricity mix and the geometric increase of stand-alone petrol/diesel generators in several quarters of the country also give environmental concern. Because of the remoteness of most rural and off-grid communities and their relatively low population, for instance, several settlements within the northern part of Nigeria, it is not economical to consider grid-extension option $[42,57,129,130]$.

The quest for solutions to the mentioned challenges, the essentiality of increasing energy access rate, minimizing the utilization of fossil fuel resources to reduce emissions and the possible relatively low life-cycle economic burden, are among the major factors that contribute to an accelerated interest in microgrids in developing countries, including Nigeria. A recent briefing on solar electricity by the Overseas Development Institute (ODI) has demonstrated that PV microgrids can supply energy for $35-53 \mathrm{~N} / \mathrm{kWh}$ compared to $40-70 \mathrm{~N} / \mathrm{kWh}$ by diesel and petrol-powered generators in Nigeria, once the financing and market limitations are addressed [40].

The adoption of a type of microgrid technology for a location is based on the locations' available energy resources and the local conditions [5,41]. The solar energy is currently the common and popular resource employed for microgrid applications in Nigeria. As earlier mentioned, some of the applications include street lighting, community-based water pumping, energy supply to community centers, schools, health center, and homes. The current issue is that there is an increased rate of solar PV systems failure, which is of great concern to communities, researchers and energy practitioners in the country.

While the average lifespan of a solar electricity project ranges from 20 to 25 years [80], a recent study has revealed that many PV systems in Nigeria fail within 2 to 3 years post-implementation [131]. In addition, several solar-powered street lights, water pumping machine, and domestic appliances that became non-functional a few years after deployment are conspicuous in several locations in the country. Several PV-based electricity systems even become dysfunctional or non-functional a few months after they have been installed [132-134]. This development is a major obstacle to the growth of solar photovoltaic industry in the country because an early failure of installed PV systems gives the technology an unfavorable reputation, in terms of performance and reliability of energy supply [40]. 
Table 4. Some of Nigeria's energy policies.

\begin{tabular}{|c|c|c|c|}
\hline Programme/Policy & Function & Policy Type & Status \\
\hline $\begin{array}{l}\text { National Energy Policy (NEP) } \\
\text { developed in } 2003[60,85]\end{array}$ & $\begin{array}{l}\text { (1) To assess and harness the country's renewable energy (RE) potential; } \\
\text { (2) To encourage the utilization of biomass resources; } \\
\text { (3) To enhance decentralized RE generation and supply in the country, } \\
\text { especially for rural areas; } \\
\text { (4) To minimize the continuous utilization of wood as fuel and encourage RE } \\
\text { systems application }\end{array}$ & Policy support & In force \\
\hline Rural Electrification Fund (REF) [85] & $\begin{array}{l}\text { (1) To increase electricity access rate across Nigeria's regions; } \\
\text { (2) To promote the expansion of national power grid and development of } \\
\text { grid-independent electrification; } \\
\text { (3) To promote rural electrification; } \\
\text { (4) To promote the use of rural electrification subsidy }\end{array}$ & Policy support (Strategic planning) & In force \\
\hline $\begin{array}{l}\text { Consumer Assistance Fund (CAF) } \\
\text { developed in } 2005[85,135]\end{array}$ & $\begin{array}{l}\text { To ensure poor energy consumers have access to the national grid power } \\
\text { supply at affordable rates through subsidy }\end{array}$ & Policy support & Planned \\
\hline $\begin{array}{l}\text { Nigerian Renewable Energy Master } \\
\text { Plan (NREMP) developed in } 2011 \text { [85] }\end{array}$ & - & $\begin{array}{l}\text { Economic instruments (direct } \\
\text { investment, infrastructure investments, } \\
\text { fiscal/financial incentives, tax relief), } \\
\text { policy support, strategic planning }\end{array}$ & In force \\
\hline $\begin{array}{l}\text { National Renewable Energy and } \\
\text { Energy Efficiency Policy (NREEEP) } \\
\text { developed in } 2015 \text { [85] }\end{array}$ & $\begin{array}{l}\text { (1) To promote the utilization of alternative energy resources for rural } \\
\text { electrification through on-grid and off-grid technologies; } \\
\text { (2) To promote efficient utilization of energy supply }\end{array}$ & Strategic planning & Planned \\
\hline $\begin{array}{l}\text { Nigeria Feed-in Tariff for Renewable } \\
\text { Energy Sourced Electricity developed } \\
\text { in } 2015 \text { [85] }\end{array}$ & $\begin{array}{l}\text { To promote the utilization of the country's untapped RE resources through } \\
\text { investments in the RE sector of the economy }\end{array}$ & $\begin{array}{l}\text { Economic instruments (fiscal, financial } \\
\text { incentives, feed-in tariffs/premiums) }\end{array}$ & In force \\
\hline
\end{tabular}


An example of failed $10 \mathrm{~kW}$ solar microgrid in Nigeria is shown in Figure 3. The system was installed in 2008 for a village located in Zamfara State, Nigeria [131]. It was designed to power street lights, two houses, a mosque and a clinic before it failed in 2010, just two years after it was commissioned.

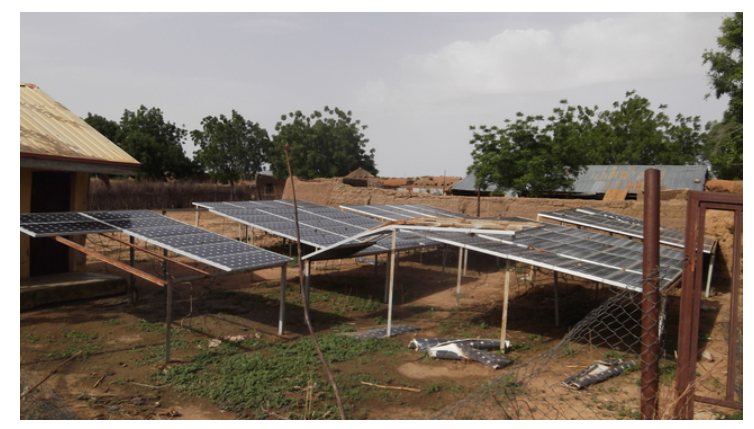

(a)

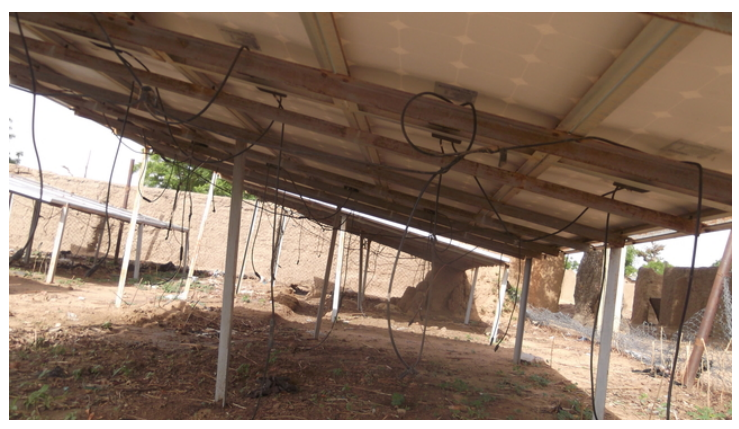

(b)

Figure 3. An example of failed $10 \mathrm{~kW}$ solar microgrid [131]: (a) The front view of the solar PV modules; (b) The back view of the solar PV modules.

Providing answers to the pertinent questions of why solar microgrids fail in Nigeria and/or what are the barriers to microgrid planning, development and sustainability is, therefore, one of the key objectives of this paper. Though Nigeria is used as a case study, it is expected that the academic contributions of the study can be useful for better understanding of microgrids, and the planning and situation analysis purposes in other countries.

\subsection{Proposed STEEP Model}

The STEEP model, proposed in this paper, is based on the fundamental sustainability principles $[41,44,45,136,137]$ and the authors' field experience. Several definitions have been provided for sustainability, but it has been defined in terms of distributed off-grid energy generation system as the "perceived potential for a system or project to endure, build a self-perpetuating capacity within a community, and ultimately reach the end of its pre-determined lifespan or evolve into another beneficial form" [41].

Therefore, in the context of this paper, we consider sustainability as the capability of the microgrids to be continually operational over its useful lifespan. While sustainability is traditionally considered to have three key components: social, environmental and economic [44], it is also crucial to examine how these perspectives could be integrated with the technical and policy dimensions for comprehensive and better insights into the issues pertaining to microgrids in off-grid communities. This is one of the major attributes of the proposed STEEP model.

There are four major criteria for decision-making in microgrid adoption and development for off-grid communities such as the need, environment, economy, and technology [56]. It is further elaborated that the mentioned criteria represent what is necessary, acceptable, affordable and feasible, respectively. In practical terms, we find that what is necessary may or may not be feasible, acceptable or feasible; what is affordable may or may not be acceptable or feasible, and vice versa. It is obvious that the mentioned criteria are partly informed by the fundamental sustainability principle. This implies that an insight into the situation and local conditions remains inevitable for developing community-based microgrids.

Therefore, given the complexity involved in planning, developing and managing microgrids and the prevailing issue of system failure, the background knowledge of sustainability and the authors' real-life experience are combined to propose the STEEP model. The model presents the microgrid failure factors (MFFs) and the sustainable microgrid factors (SMFs) by integrating the social, technical, 
economic, environmental and policy perspectives. Some existing studies have considered the SWOT framework for analysing the status, prospect, and issues of renewable energy-based distributed generation technologies [138-142]. The SWOT is essentially a matrix of identified strength, weakness, opportunities and threats, where the weakness and the threats are considered to be the internal issues and the external factors, respectively, that affect the specified technology [139].

Though such an approach is widely used by energy researchers to ascertain the prospects of energy technologies in a location or country, we introduce the STEEP model in this paper to provide some answers to the practical question of why PV microgrids fail in Nigeria. This is because a deeper understanding of the situation and the local conditions is required, which is why the STEEP model has been proposed that clearly identifies and classifies issues as social (S), technical (T), economic (E), environmental $(\mathrm{E})$ and policy $(\mathrm{P})$ with the overall aim of achieving sustainable microgrids through collective actions of the concerned stakeholders.

The issues surrounding the system's failure transcend disciplinary boundaries, therefore, classifying the problems and the possible solutions into the afore-mentioned perspectives provides the opportunity for stakeholders to consider and approach the situation from a multidisciplinary point of view. How the STEEP model is applied is illustrated in Figure 4. It is first employed to discuss both the MFFs and the SMFs, while its application to the sustainable planning framework (SPF) will later be presented in the paper.

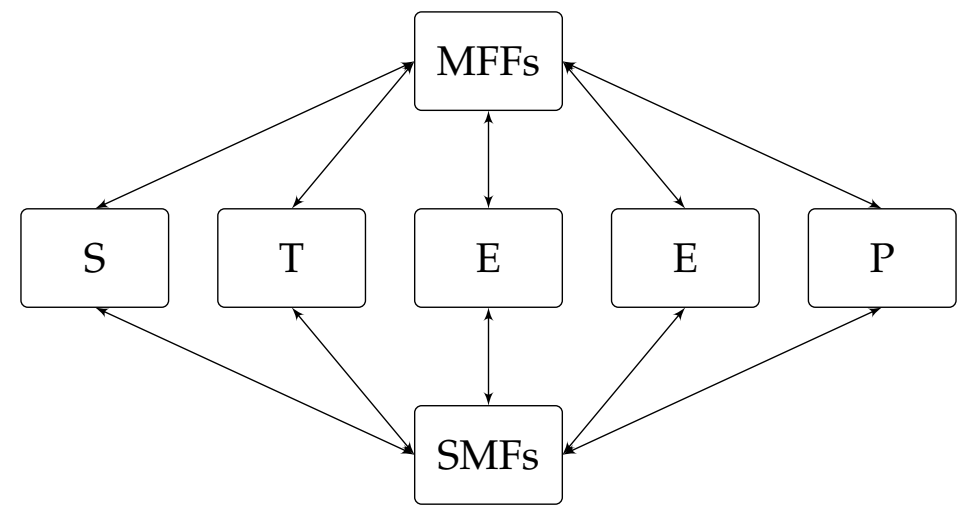

Figure 4. STEEP model application.

\section{Microgrid Failure Factors (MFFs)}

\subsection{Social}

\subsubsection{Lack of Community Engagement}

One of the major factors responsible for microgrid failure is that there is the lack of community interaction and engagement during the system planning stage. Since the microgrid is designed for a community, it is necessary to involve the stakeholders of the community to achieve a sustainable energy planning and development. The donation of renewable energy systems such as PV-based street lighting, water pumping systems to communities is common in Nigeria, without a structured community engagement in sustaining the systems. Moreover, the issue of land is a major problem in a situation where there is no mutual-agreement between the planners, developers, financiers or investors, or the government, and the community.

\subsubsection{Lack of Education}

There is the lack of knowledge of the best way to utilize energy. Most remote households still use inefficient appliances, whose impacts are usually not considered before the implementation of the 
energy system. In addition, most of them are not educated on how to conserve energy; for instance, lighting fittings are not usually switched-off during the day in several homes when not needed.

The lack of education on the need for maintenance is another issue that contribute to microgrid failure in the country. Generally, solar photovoltaic systems are usually considered as energy technologies with a low maintenance requirement $[81,131,143,144]$. This is usually misconstrued and interpreted as a no maintenance requirement, which is why several PV-based systems in the country fail and abandoned a few years after installation.

\subsubsection{The Question of Ownership}

Most of the existing solar microgrids have been deployed as donations to rural communities by politicians usually for election campaigns or fulfilling promises to contribute to their local constituencies after the election. This practice, no doubt, increases the application of renewable energy systems, but it does not guarantee a sustainable energy supply. One main reason for this is that the communities to which such systems are donated do not assume the ownership of the infrastructure. In this situation, the communities usually expect that the responsibility to operate and maintain the donated systems rest with the donors. In this situation, the communities usually expect that the responsibility to operate and maintain the donated systems rest with the donors. A similar situation has also been emphasised in [145].

\subsubsection{Installation by Unqualified/inexperienced Practitioners}

The notion by many in the country is that PV systems installation is a plug-and-play exercise, which is one of the factors that attract an increased number of unqualified and inexperienced installers and practitioners. Awarding energy projects to unqualified practitioners or contractors usually compromise the standard and quality of the work.

In most cases, installations by the unqualified personnel are driven by the act of minimizing cost without proper consideration for the energy consumption pattern, variable power output and the possibility of users' load growth. Providing a cost-effective solution is necessary in engineering practices, but it is crucial not to compromise the technical aspect of the project. There are a few qualified and experienced photovoltaic technicians in the country that can install and maintain systems compared to the need and situation [40].

\subsubsection{Lack of Practical Preliminary Survey}

Based on the authors' field experience in remote communities, the lack of practical pre-design survey and assessment is one the major social factor that contributes to microgrid failure. Providing a microgrid solution is beyond employing second-hand information about the intended users or communities. A survey is crucial to obtain the required data (i.e., first-hand information) on which the engineering design will be based. The interaction with the proposed communities or energy users usually provides an insight into their situation, needs, preferences and opinions, etc., that are necessary for planning purposes.

\subsubsection{Low-Level of Social Awareness}

The lack of awareness about renewable energies and the understanding of how microgrid systems work are among the factors that contribute to system failure. It is indisputable that a system that is not understood cannot be managed. The awareness about renewable energy-based microgrids needs to go beyond mere optimism that such technologies are promising options for increasing the electricity access rate in the country. It is estimated that about $40 \%$ of Nigeria's population is not aware of solar photovoltaic system [40]. 


\subsubsection{Insecurity of Infrastructure}

The vandalization and theft of energy generation equipment or component is a common challenge affecting both the centralized and de-centralized power systems in Nigeria. Past occurrences reveal that such an evil is usually perpetrated by some hoodlums or thugs within the communities or from neighboring communities, with deliberate damage of the system or stealing of the solar PV modules. Communities are conscious of this but the failure to secure the installed microgrid systems give the hoodlums the opportunity to steal or damage the systems.

\subsection{Technical}

\subsubsection{Poor and Inappropriate Design}

The design, modeling and planning of renewable energy-based microgrids are different from those of conventional petrol or diesel-powered systems with which most are already familiar [81,146,147]. We have found that poor design is one of the major factors that curtail the lifespan of microgrids. Renewable energy systems design involves a deep understanding of the available energy resources and the users' demand [148], and how changes in these can affect the availability or reliability of energy supply. Several designs are found to be optimistic without due considerations for the what if or worst-case scenario. An example of such a scenario is the increase in the users' energy consumption and its effect on the microgrid system.

For instance, the aftermath of an underrated photovoltaic array is that it will not provide the sufficient charging current for the battery. At the early stage of the microgrid system, the energy output appears to be sufficient for the users' demand; however, as time goes on, the available energy output reduces due to the insufficient charge on the battery bank and the system will eventually fail when the battery's depth of discharge (DoD) has reached zero. The orientation of the solar PV modules is also important. Several solar PV arrays were not tilted to the required angle. These are part of the peculiar problems, and are attributed to the lack of technical expertise in Nigeria.

\subsubsection{Lack of Standard Maintenance Procedures}

The lack of standard maintenance procedures, such as preventive/corrective measures, is one of the key factors that affect the sustainability of microgrid in the country. Apart from the misinterpretation of solar photovoltaic systems as technologies that do not require maintenance, the maintenance culture and procedures are also lacking in the country. Solar photovoltaic systems performance, for instance, is affected by dust, wiring losses, etc., apart from the solar irradiance and ambient temperature factors [81]. Several solar arrays within the remote communities are usually dusty and the aftermath is a reduction of the systems' energy output.

\subsubsection{Dearth of Local Skilled Practitioners}

The lack of local expertise is a key factor that contributes to the award of renewable energy contracts to foreign experts. The issue with this arrangement is that some of these experts are not familiar with the local conditions, and they will have to go back to their countries after the project implementation. They are not available for the continuous operation and maintenance of the systems. Because trained/skilled experts are lacking in the country, the foreign experts need to be depended on somehow for the technical sustainability of the microgrid systems, e.g. maintenance.

\subsubsection{Lack of Conformity to International Standard Codes}

There are standard international codes which guide the design and implementation of microgrids such as those presented by the IEEE, IEC, etc. [81,149-151]. Most microgrids do not conform to standards and they fail within a few years after installation. 


\subsubsection{Use of Sub-Standard Materials}

A common practice that also leads to microgrid failure is the use of sub-standard materials and components such as solar PV modules, battery cells, and inverters/controllers. Generally, renewable energy-based microgrids have a high initial capital cost but the quality of the system is compromised when low-cost sub-standard materials are used. This problem is usually dictated by the economic benefit that may be realized by the installers, the contractors or the client by avoiding the use of approved and standard materials.

\subsubsection{Inadequate Knowledge of Renewable Energy}

Despite the recent awareness of solar photovoltaic systems and the optimism that such systems have the potential to address the energy shortage challenge in the remote communities, the knowledge about the features and characteristics of renewable energies is still lacking [5,19,41,85,125]. The intermittent and variable nature of renewable energy must be well understood.

The lack of knowledge about renewable energy characteristics is one of the reasons why most designs are optimistic, i.e., based on the dry season's potential when there is a high solar irradiation cycle. Such designs do not often consider the impact of the rainy season with relatively low solar irradiation cycle, which is why several systems fail during the rainy season.

\subsubsection{Lack of Monitoring Systems}

The role of monitoring systems in the operation and maintenance of microgrid systems cannot be over-emphasized $[6,80]$. An example of such systems is the one employed for remote monitoring of rural microgrid systems, which is usually networked with computers. This is lacking, and it contributes to system failure as the maintenance process is often limited only to corrective measures.

\subsubsection{Poor Project Supervision}

The best practices require that projects must be well-supervised by a qualified person before it is certified and commissioned. Projects are often left in the hands of contractors to install and supervise, which is why the quality of several projects are compromised. The poor supervision of microgrids in the country is one of the potential factors that contribute to their collapse in their early years post-implementation.

\subsection{Economic}

\subsubsection{Lack of Financial Support by the Government}

In most industrialized countries, governments play a major role in supporting and promoting renewable energy systems [1]. One way of achieving this is through a financial support. This is lacking in Nigeria and it contributes to microgrid failure. Many communities have the interests in adopting microgrids but the lack of financing or the uncertainties in securing financial support has hampered their plans and aspirations [125].

\subsubsection{The Question of Who Takes the Financial Responsibility}

As earlier mentioned, several PV-based microgrids were donated to the communities by politicians. Based on this arrangement, the communities do not assume the ownership of the microgrids and this raises a question of who takes the financial responsibility of managing the operation and maintenance $(\mathrm{O}$ and $\mathrm{M})$ of the microgrids.

\subsubsection{Lack of Financial Framework}

Successful deployments of microgrids usually depend on a sustainable financial framework that involves the government, private sector, communities and other concerned stakeholders. The absence 
of financial models is one of the major causes of microgrids failure and deterrent to their widespread application in the country

\subsubsection{Lack of Revenue Generation}

A good microgrid system is expected to be self-supporting in terms of income or revenue generation, arising from the energy services to the intended users in the community. This initiative is usually done for sustainable management of the microgrid system, i.e., operation and maintenance. Such an initiative is lacking, and it leads to system failure as there are no commitments by communities or users to pay for the energy services.

\subsubsection{High Cost of Component Replacements}

The high cost of replacing microgrid components, especially the BOS-battery cells, inverters, circuit breakers, and the lack of financial capability to effect replacements of the components are part of the factors that contribute to microgrid failure.

\subsection{Environmental}

Though the environmental aspect is not a direct cause of system failure in the context of this paper, it has been carefully considered as a vital ingredient of sustainability. Therefore, the identified issues and the relevance of the environmental dimension are discussed under the MFFs in terms of microgrid planning, development, management and sustainability.

\subsubsection{Dearth of Comprehensive Energy Resources Assessment}

The best practices require a comprehensive analysis of the location's energy resources so as to ascertain the resource or resources that will possibly give best solution(s). This exercise is one of the fundamental requirements for planning and developing microgrids.

However, microgrid technology selection has rather been based on subjective choices in several communities [145]. Microgrid applications seemed to be limited to solar photovoltaic in the country because of the dearth of detailed energy resources assessment that can reveal all the available resources at a particular site of interest.

\subsubsection{Lack of Planned Environmental Assessment}

Environmental impact assessment (EIA) is an important aspect of system planning that seeks to evaluate proposed energy systems and their likely implications for the environment before decisions are made to implement them. The EIA also suggests appropriate responses to the potential issues [152,153]. This process, which is one of the pathways to sustainable energy system planning and development that needs to be well pronounced, strengthened and incorporated in microgrid solutions, even though there is an existing EIA Decree in the country [154].

Notwithstanding the lower environmental impact of solar photovoltaic microgrids compared to the wind and hydropower systems, the issues associated with the end-of-life management-disposal and/or recycling of PV modules and battery banks are part of what need to be taken seriously for environmental sustainability [155]. This aspect needs to be coordinated with effective policies.

\subsubsection{Weak Environmental Awareness}

Renewable energy technologies are not without environmental impacts. They are clean energy systems but there is the need to understand that there is some amount of energy flows associated with their life cycle. Such energy flows reveal the primary energy demand and the carbon emissions produced from their manufacture to when they are de-commissioned, usually referred to as cradle-to-grave or lifecycle impact analysis [156]. 
A practical scenario of a lack of environmental awareness is the improper disposal of dangerous materials such as compact fluorescent tubes (CFLs) and battery cells (e.g. lead-acid cells) after their useful life. Several users dispose these materials as normal waste. Having the proper education and knowledge will help to address the situation.

\subsection{Policy}

\subsubsection{Ineffective Policy Initiatives}

Widespread applications of microgrid systems are achieved in developed countries and some developing countries such as South African, India, etc. [1] through effective policy frameworks. It is impossible to achieve sustainable microgrids in the absence of appropriate policy measures. Such policies work together with other aspects-social, technical, economic factors to achieve the desired results. Examples of existing policies in other parts of the world are feed-in tariffs (FiTs), feed-in premiums (FiPs), net metering/net billing, tax credits/incentives, etc. [1]. Therefore, the lack of effective policies is one of the major factors that contribute to microgrid failure in Nigeria.

\subsubsection{Lack of Political Will for Widespread Application}

Many governments and decision-makers around the world are recognised as being a major player in the promotion and widespread application of renewable energy-based microgrids [1,3]. The lack of political will has been identified as one of the major problems leading to microgrid failure [124,125]. Furthermore, where the government has demonstrated the political will, the issue of uncertainty and political instability has been a major obstacle.

\subsubsection{Ineffective Frameworks That Encourage Private Sector}

The role of the private sector in the economic advancement of a country cannot be over-emphasized. Policy frameworks are implemented and aimed at attracting stakeholders, players or investors with clear vision and interest from the private sector toward renewable energy project deployments and development. Public-private-partnerships (PPPs) is an example of such alliance, but its ineffectiveness hampers the uptake of microgrid technologies. Private sector's interest and involvement in rural electrification is limited because of the economic status of the consumers (i.e., lack of financial capacity to pay) $[40,125]$. The ineffective regulatory frameworks for renewable energy market is a major obstacle to the growth of microgrids in the country.

\subsubsection{Ineffective Quality Control Policies}

The use of sub-standard products and materials such as solar PV modules, battery cells, and inverter/controller are part of the factors that contribute to microgrid failure in Nigeria. The policy guiding the importation of these materials appears to be weak, which is why the country has been a dumping ground for cheap and adulterated components and materials.

\section{Sustainable Microgrid Factors (SMFs)}

The effect of higher failure rates of PV microgrids in the country has resulted in a negative view among energy users, communities, clients, donors or philanthropists that electricity generation through the solar photovoltaic technology is not viable in Nigeria [40].

This development indicates that solar photovoltaic microgrids have earned a poor reputation in terms of electrical performance and reliability of supply, which requires urgent intervention by the government, researchers, solar photovoltaic technicians, engineers, sociologists, economists, environmental engineers and planners, policy-making agencies, and the relevant government institutions such as Council for the Regulation of Engineering in Nigeria (COREN), Energy Commission of Nigeria (ECN), Standard Organisation of Nigeria (SON), Federal Ministry of Science and Technology 
(FMST), National Agency for Science and Engineering Infrastructure (NASENI), Rural Electrification Agency (REA), etc., so as to secure the future of renewable energy technologies in the country.

Having identified, classified and defined the MFFs, this paper recommends the SMFs that can help mitigate the potential factors contributing to microgrid failure in the country. The SMFs are detailed as follows.

\subsection{Social}

\subsubsection{Effective Community Participation}

An effective social engagement through community participation is one of the factors necessary to achieve a long-term viability of microgrid systems. This is because the involvement of the community development association (CDA), the community chiefs or leaders and members of the community is a means of making them have a sense of belonging in the microgrid planning, development, and management processes. Therefore, the communities will be willing to lend their support for achieving the desired results such as helping to address the issue of land or finding suitable sites.

The social acceptance of the energy technology being proposed is an important factor that will determine the level of participation of the community [130]. For instance, the fact that an energy solution is cost-effective or feasible does not mean that it is acceptable in a community. This shows the significance of involving the community in the energy development process. Consulting the community is key.

\subsubsection{Educating the Public}

Educating the user or public on the energy efficiency, conservation, and utilization practices is one factor that can help to forestall the collapse of solar microgrids. Such practices involve the use of energy saving and smart appliances and the culture of switching off appliances such as TVs, radios, DVD players and lighting when the users are not at home.

Furthermore, one of the benefits of an effective community participation is that it creates a platform for educating the communities and stakeholders on the essentiality of routine maintenance of the energy infrastructure. The users and the communities need to be informed to correct the misconception that solar photovoltaic microgrids require no maintenance. One way to achieve this is by incorporating renewable energy studies and training in students' curriculum in schools and organizing public workshops and hearings by PV practitioners and technicians to educate the people.

\subsubsection{Defining the Infrastructure Ownership}

Determining the ownership structure makes the overall goals of proposing and developing energy infrastructure clearer to the stakeholders. A community microgrid may be owned by the community, the local/state or federal government, or by a private organization or by a joint venture [146,157]. Understanding who owns the facility will specify the roles and responsibilities expected of the communities or the energy provider, and it is one crucial sustainable factor.

\subsubsection{Awarding Projects to Qualified Contractors}

One of the steps to achieving sustainable microgrids in remote communities is by awarding projects to qualified practitioners or contractors. This implies that the award of projects will be based on the contractor's training, expertise and long-standing merit and experience in the installation of off-grid or rural electrification systems. If this factor is carefully considered, the system's failure will be mitigated.

\subsubsection{Effective Pre-Design Survey}

This aspect involves conducting a preliminary survey prior the detailed microgrid's design, implementation and post-implementation $[146,158,159]$. An effective community participation 
provides the opportunity to assess the energy situation and needs of the intended users, loads and the energy consumption pattern, preferences and opinions and the available energy resources within the site. One way to achieve this is by visiting the community and then assessing the appliances-on-site survey and making observations [160]. First-hand information will be obtained through this process, which will be useful for practical microgrid design. This aspect is essential because the users need to be understood for achieving sustainable localized microgrids.

\subsubsection{Effective Awareness Programme}

Effective awareness programmes and initiatives can provide a better way of understanding how microgrids work. Such programmes will heighten the prospective energy consumers' awareness, as well as those of the potential investors and entrepreneurs and the industries. Researchers, academic institutions, solar practitioners and the relevant government agencies can do more by furnishing the public with the knowledge they need about renewable energy microgrids. Such efforts not only seek to improve the current situation but also provide better insights into new business opportunities that could lead to widespread application.

\subsubsection{Security for Energy Infrastructure}

Another feature of an effective community participation in the planning and development of microgrids is the joint effort towards providing adequate security for the infrastructure. In this wise, the community is expected to assume the responsibility of protecting the microgrid from theft and vandalization by hoodlums. Providing security for the systems is one of the factors that can help achieve their long-term operation. Furthermore, it is reasonable to consider security systems or apparatus that can forestall cyber-attacks on the localized energy systems in the future. Though the current experience is majorly on vandalization and theft, the cyber-security plan becomes necessary because of the previous experiences such as the BlackEnergy 3 and Stuxnet that had clearly presented the vulnerability of the current power network [161].

\subsection{Technical}

\subsubsection{Appropriate and Realistic Design}

Establishing a platform to advocate appropriate and realistic design is one of the factors toward sustainable microgrid applications in the country. The onus is not only on the government but also on all the concerned stakeholders such as engineers, researchers, technicians, academic institutions, agencies, etc. This is because adequate technical knowledge is necessary for developing or creating realistic microgrid designs. This knowledge can be obtained through training.

In recent times, efforts are being made by government agencies to address the problem of a dearth of local experts in solar PV systems through training. For instance, the Lagos Electricity Board established the Lagos Energy Academy (LEA) in 2014 for the training of students on solar electricity system installation and maintenance [40]. The widespread training of students and technicians across Nigeria's regions will help to build local capacity.

\subsubsection{Standard Maintenance Procedure}

The importance of effective maintenance in achieving sustainable microgrids cannot be overemphasized. Appropriate systems design and routine maintenance are a necessary technical aspect that is of priority in microgrid planning, development, and management. Cleaning the dust on solar PV modules, checking the battery contacts, replacing battery cells, inverter/controller and circuit breakers, etc. when they fail are part of the maintenance exercise. A certain level of knowledge is also needed to be able to maintain microgrids, and which can also be developed through training of the concern stakeholders. Microgrid models thrive on multi-dimensional factors, of which maintenance is one. 


\subsubsection{Use of International Standards}

The international technical standards provide guidelines for designing, planning and developing microgrids. Such recommendations help to minimize systems failure, even though the local conditions need to be considered.

As opposed to optimistic designs, realistic designs consider the worst-case scenario, for instance, using the lowest solar irradiation and the highest users' demand as the basis for determining the solar microgrid capacity as recommended by the international standard [81].

Such a technical consideration does not only cover the dry season when there is high solar irradiation cycle but also examines the possible microgrid output during the rainy season when there is relatively low solar irradiation cycle, including the effect of losses due to temperature and dust. This knowledge/approach will be useful for minimizing systems failure due to underrated solar photovoltaic arrays in the country.

\subsubsection{Use of Quality and Approved Materials}

This is one of the ways to mitigate the problem of systems failure and there is the need to enforce the use of quality and approved materials in Nigeria's engineering practices. The concerned government agencies need to be effective and strengthened in this aspect to salvage the country's future renewable energy industry and market. They should be actively involved and committed to ensuring that adulterated and low-quality materials are banned and not allowed in the market.

\subsubsection{Use of Remote Monitoring Systems}

The monitoring systems can help to forestall systems failure by providing real-time information about the performance of the microgrid. It is one thing to design, model or simulate the performance of microgrids prior implementation, it is another thing to be able to monitor their real-life performance after implementation. By using a remote monitoring system, the technician does not have to be at the microgrid site for 24-h. This can help minimise the complexity involved in microgrid operation and management.

\subsubsection{Effective Project Supervision}

There is the need to enforce an effective project supervision as a pre-condition for certifying and commissioning microgrids. Such an action is one of the factors that can help to mitigate systems failure. This aspect is expected to be handled by a qualified and experienced energy expert, whose major responsibility is to ensure that the quality of the project is not compromised. The proactiveness of the government through its concerned agencies is necessary to ensure that energy projects are properly supervised.

\subsection{Economic}

\subsubsection{Financial Support by Government}

The government has a major role to play in ensuring sustainable microgrid development and management in the country by providing a financial support. Findings show that some of the communities are willing to embark on microgrid projects that will give them a self-determination but the uncertainties about the success due to a lack of financial capacity and support is a major impediment to such an ambition and interest. The government can provide support through grants, loans or tax credits as it were in other countries [158]. A relatively lower cost of loans by the government will encourage investments in RE projects in the country [40]. 


\subsubsection{Financial Commitment by Communities}

Microgrids are localized solutions and their sustainability relies not only on the capability to provide the initial capital costs but also on revenue generation. This is key to sustainable operation and maintenance of microgrids. Microgrid models that attract the readiness or willingness of the intended communities to pay for energy services will attract potential investors and developers. Such will facilitate a long-term viability of microgrid systems in the remote communities. Clean Development Mechanism (CDM) is one of the means by which community-based microgrids could be sustained [143].

\subsubsection{Financial Models to Integrate RE Entrepreneurs}

Sound financial frameworks are necessary to attract and integrate renewable energy entrepreneurs toward the microgrid business and development. Though microgrids still remain an emerging energy technology, the government needs to be proactive in creating an enabling financial platform for them to thrive.

The government has promised to promote a market-oriented approach to rural electrification in Nigeria that involves communities, energy operators and developers [40], which is expected to be a pathway to addressing the financial barriers in the near future.

\subsubsection{Incentives and Low Import Duty}

Currently, a complete solar photovoltaic device-PV modules, batteries, etc., attracts a minimum import duty of $21 \%$ [40]. A reduced import duty on RE materials and components is one of the factors that can encourage rural small and medium enterprises (SMEs) and communities. The introduction of subsidies and other financial incentives such as FiTs, FiPs, etc., will also promote microgrids. The Nigeria Feed-in Tariff for Renewable Energy Sourced Electricity has been developed by the government in 2015, and it is expected to strengthen the RE-based microgrid industry in the future [85].

\subsection{Environmental}

\subsubsection{Site-Specific Resources Report}

Rural electrification through microgrids is a localized energy solution. A comprehensive report on the available energy resources in the community or location is a requirement for planning purposes. Such a report details the energy potential and the environmental or climatic factors that need to be considered during the planning process. In planning, the designer or energy expert is interested in providing optimal energy options in a situation where there is more than one source of energy. A site-specific energy resources report will reveal the fuels available and decisions will be made based on these. This environmental perspective, combined with the technical aspect will provide a better planning strategy.

\subsubsection{Effective EIA}

Planning and developing microgrids does not only depend on the socio-technical and economic factors but also depend on the environmental aspect as well. An effective EIA reveals the impacts or consequences of the proposed microgrid system prior implementation.

As earlier discussed that there are four major criteria for decision-making in microgrid adoption and development for off-grid communities; these are the need, environment, economy, and technology [56]. These criteria represent what is necessary, acceptable, affordable and feasible, respectively. However, what is necessary may or may not be feasible or acceptable; what is affordable may or may not be acceptable or feasible, and vice versa.

Therefore, designing a cost-effective or affordable energy system and locating the right market is not enough in planning microgrids, as the other aspect like the environmental factor must be considered for a long-term viability in the specified community or location. 


\subsubsection{Effective Environmental Awareness and Research}

It is part of ensuring environmental sustainability to encourage and promote deployment of environmentally friendly solutions. Sound microgrid models based on renewable energies are key to achieving this objective. Also, having the proper education, knowledge or awareness will help to address the issue of improper disposal of dangerous materials such as CFLs and battery cells [162].

Furthermore, it is important to advance the microgrid knowledge by engaging in quantitative research that assesses and evaluates the life cycle impact of energy solutions. The environmental performance parameters that will be of interest in this case include the life cycle emissions (LCE), global warming potential (GWP), cumulative energy demand (CED), energy payback time (EPBT) and net energy ratio (NER) or energy return on investment (EROI), which can aid the understanding of the comparison of the impacts of renewable energies with those of conventional energy sources [163-165]. This will form a direction for future research.

\subsection{Policy}

\subsubsection{Political Support}

A conscious political support is one of the key factors for achieving a long-term viability of microgrids. This involves strengthening the existing government policies that will not only address the problem of system failure but also promote the uptake and widespread application of microgrids in the country. The government policies need to be clear and certain. Also, a conscious and firm political support is required to support an effective policy that could abolish the implementation of energy infrastructure by unqualified persons in the country.

\subsubsection{Established and Strengthened PPPs}

Though microgrid is a nascent market in Nigeria, it is necessary for the policy-makers to explore the possibility of public-private partnerships. Such an initiative will encourage the private sector and in a way, address the issue of doubts and uncertainties about the viability of microgrids in the country. Another benefit of an effective PPP policy is that it provides the opportunity to attract foreign investors toward microgrid business and development in the country.

\subsubsection{Strengthened and Stable Market Regulatory Framework}

The uncertainties about the microgrid market are part of the factors hampering its growth in the country. Currently, the fossil fuel market seems to be attractive to investors compared to the renewable energy market. A favorable and stable market policy is key to the long-term viability of microgrids in Nigeria. This is because the private sector, financiers or investors will want to be sure that the market policy is not only favorable, but also stable to facilitate a healthy and profitable investment into the future.

\subsubsection{Strengthened Quality Control Measures}

Ensuring quality and standard materials is fundamental to the sustainability of microgrids. The importation and widespread use of sub-standard products is prevalent in Nigeria because the consequences appear to be weak. Therefore, this problem can be mitigated by strengthening the quality control policies or measures in the country and ensuring compliance and pronouncing appropriate consequences on defaulters.

\section{Sustainable Planning Framework (SPF)}

This study has demonstrated that the understanding of the prevailing situation and local conditions is key to identifying the MFFs and SMFs. Yet, there is the need to present a generalized framework that will be useful for sustainable planning of microgrid systems in any location around 
the world. The goal of such a framework is to serve as a guide of important processes for considering the development of microgrids for off-grid communities.

In other words, the complexity and the several factors involved in the situation, local conditions and energy planning analyses require not only a deeper understanding of the problem and how it could be mitigated, but also an effective framework that can help realise sustainability [166].

This study finds that there are multiple dimensions to the identified problem. Hence, the need for a multidimensional framework such as the STEEP model, which examines the interwoven factors that transcend the traditional techno-economic energy systems planning framework [155,167-169]. Therefore, based on the MFFs and SMFs, best practices and practical experience, the sustainable planning framework (SPF) is presented in Figure 5, which summarises some of the factors or processes that could aid the understanding of microgrid development.

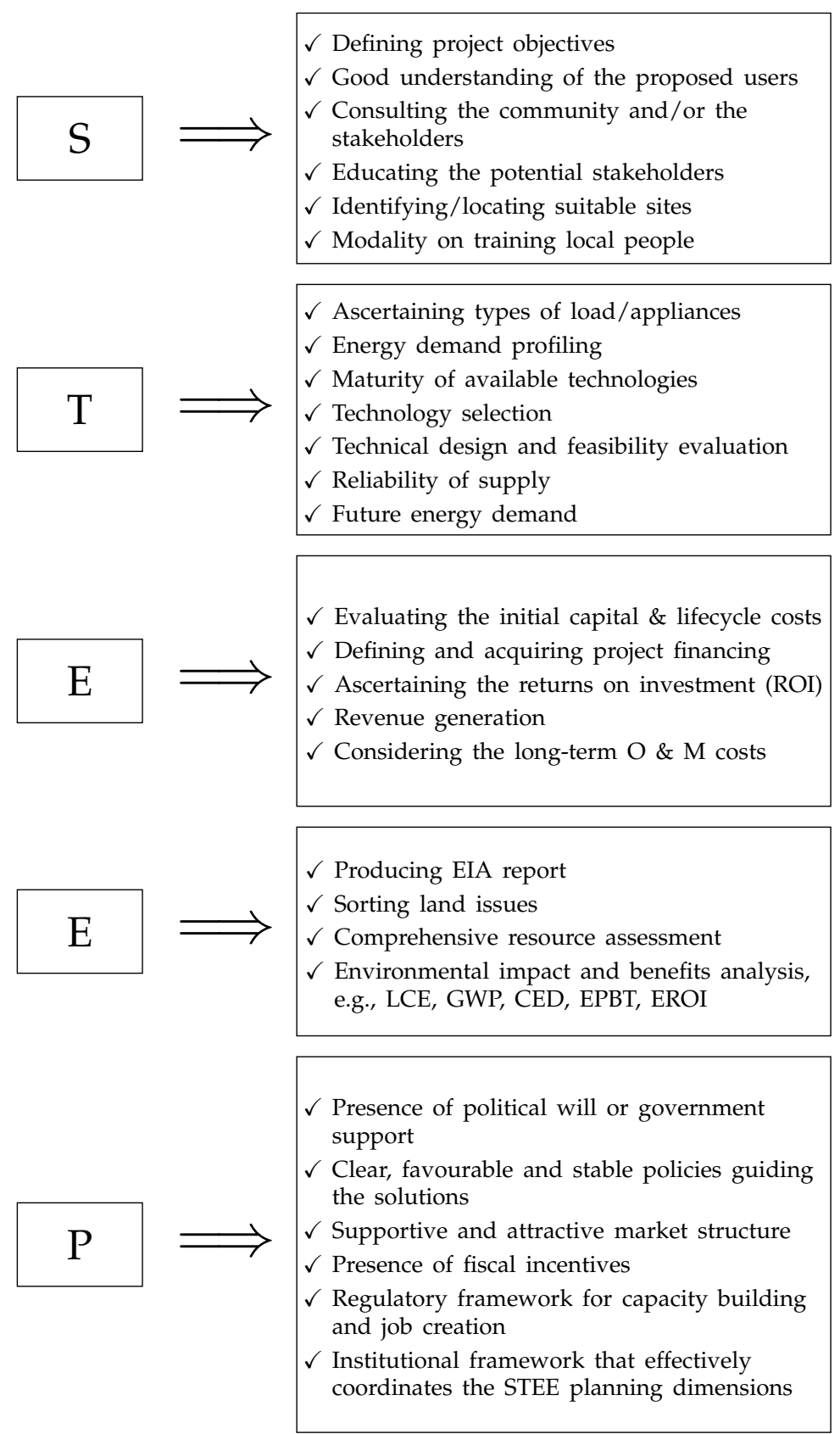

Figure 5. Sustainable planning framework. 
An urgent attention of the decision-makers and stakeholders is needed to devise the possible solutions by first deciphering the multi-faceted issues defined by the proposed STEEP model, and then, coming to terms to mitigate them and foster sustainable microgrid developments in the country. This is necessary to correct the negative impression of the public about solar photovoltaic microgrids, for the purpose of promoting the interest in and application of microgrids for rural electrification in the future.

Addressing the grand challenge in the absence of any of the five element of the STEEP model means an incomplete solution. This is because all the dimensions work together to achieve the desired sustainable energy development. For instance, if the social (S) perspective is not duly integrated with the plan, it means the remaining part, i.e., the TEEP will have a missing link between the stakeholders such as the users and the intended community, planners, solution provider or financier. Therefore, the objectives of the proposed energy solutions must be clearly understood with adequate considerations for the intended users.

Furthermore, if the policy $(\mathrm{P})$ aspect, for instance, is not appropriately and adequately considered in the planning and development process, the remaining part, i.e., the STEE, is bound to fail because of the lack of effective, supportive or suitable regulatory framework. This is also the case with every other dimension of the model, indicating the essentiality of all the five fundamental elements of the STEEP model.

Apart from the use of the proposed STEEP model for understanding the issue of microgrid failure and the sustainable factors in this paper, it can also be used as the basis for developing a multi-criteria analysis for selecting energy technologies for remote communities. Our future work will consider the application of the STEEP model for selecting suitable localized renewable energy system(s) for rural electrification purposes using the multi-criteria problem and analysis approach.

\section{Prospects of Microgrids}

It is also of interest in this paper to present the prospects of sustainable microgrid technologies, especially those that are based on the productive and economic applications $[57,119,130,145,170,171]$. This is because the benefits of microgrid technologies go beyond the domestic or household applications, and can help to empower the proposed users and communities.

- Microgrid-powered street/community lighting or stand-alone lighting systems have the potential to create the opportunity for evening time activities/businesses within the local or remote communities. It does not only improve the people's lifestyle but also increase safety at nights. Other promising technologies for street or community lighting in the future are bio-diesel, fuel cells-powered engines and small hydropower.

- Microgrid systems based on hybrid renewable energy resources can be a suitable option for cooling, and refrigeration/preservation of food using energy efficient refrigerators. This will help minimise the wastage of agricultural goods and products such as fish, crab, fruits, and maximize profits.

- Solar thermal and biomass-based microgrids are a promising option for generating heat for agricultural processes and households. Such an option can help save time wasted in collecting fuelwood for generating heat energy.

- Solar photovoltaic microgrids have the potential to create business opportunities in the remote communities such as mobile phone charging stations, internet cafes, computer and ICT centers. This will reduce the time needed by residents of remote communities in traveling to other localities for the aforementioned services.

- Solar photovoltaic microgrids for water pumping is a promising option for agricultural processing and irrigation purposes, including domestic application. A biodiesel-powered water pumping machine is a possible option for future purpose.

There are other technologies such as solar cookers, solar dryers and biogas cookers, which are also eco-friendly options for remote communities. Some of these technologies are already in use in the 
country but the major challenge of several solar microgrids is that they fail a few years after installation, i.e., 2 to 3 years as presented in [131].

Some existing studies in the literature have presented general barriers to renewable energy systems and microgrid systems development and application $[19,59,66,68,85,119,124,125,169]$, however, this paper has proposed the STEEP framework for better insights into the issue of microgrid failure and barriers to microgrid planning, development and sustainability, how to mitigate barriers/drawbacks, and a general basis for planning localised microgrids/renewable energy systems for any location. Such a framework provides a holistic approach to capturing the issues and enabling factors of energy systems, which can aid the understanding of and future contributions in microgrids.

\section{Conclusions}

This paper has presented a comprehensive review of microgrid technologies focusing on solar photovoltaic, wind, hydro, biomass and conventional energy systems, their developmental status and applications.

The study found that the lack of adequate considerations for the enabling factors is a major reason why microgrids fail in several off-grid communities. It is against this backdrop that research efforts are required that consider better strategies and framework for achieving sustainable microgrids in remote communities.

The research has proposed the STEEP model to examine critically the prevailing microgrid failure factors based on the social, technical, economic, environmental and policy perspectives. The model has been derived from the fundamental sustainability principles, best practices, and the authors' practical experience, and detailed the sustainable microgrid factors, key dimensions and actions, which are necessary for addressing the barrier of microgrid failure in remote communities.

Using remote communities within Nigeria, West Africa, as case studies, the paper demonstrated the need for the STEEP approach for better understanding of microgrid planning and development for rural and peri-urban communities. Such an approach thoroughly considered the prevailing situation and local conditions in ascertaining the causes of failure and the possible ways to mitigate the problems. Having identified the multi-dimensional factors presented by the challenge, the study provides a platform for actions and efforts by the concerned stakeholders - government, investors, financiers, developers, researchers, technicians, etc. toward addressing the problem of systems failure. This joint effort is necessary because of the interwoven nature of the enabling factors. The STEEP approach and analysis can be useful for assessing the energy situation of any community or country around the world.

Having better insights into microgrid systems planning, development and management are expected to address the drawbacks and improve the situation, some of which consider the effective community participation, appropriate and realistic system design, effective maintenance, sound financial framework, revenue generation, education of the public, training and building local expertise, environmental impact considerations and benefits, stable and favorable policies, fiscal incentives, etc. The research has introduced the sustainable planning framework (SPF), which can form a general basis for planning microgrid systems in any remote location.

This study revealed that certain enabling factors and favorable political environment are necessary to achieve widespread and sustainable microgrid applications in off-grid communities around the world, such as those based on the social, technical, economic, environmental and policy perspectives.

Acknowledgments: D. Akinyele and Y. Levron were supported by Grand Technion Energy Program (GTEP) and a Technion fellowship.

Author Contributions: All authors have worked on this research together and they have approved the paper.

Conflicts of Interest: The authors declare no conflicts of interest. 


\section{References}

1. Renewables 2017 Global Status Report; Renewable Energy Policy Network for the 21st Century; Technical Report; Paris Cedex, France, 2017. Available online: http:/ / www.ren21.net/wp-content/uploads/2017/ 06/17-8399_GSR_2017_Full_Report_0621_Opt.pdf (accessed on 23 October 2017).

2. Enerdata. Available online: https:/ / yearbook.enerdata.net/ (accessed on 23 October 2017).

3. U.S. Energy Information Administration. International Energy Outlook; Technical Report; U.S. Energy Information Administration: Washington, DC, USA, 2016.

4. Ainah, P.K.; Folly, K.A. Development of micro-grid in sub-Saharan Africa: An overview. Int. Rev. Electr. Eng. 2015, 10, 633-645.

5. Akinyele, D.; Rayudu, R. Strategy for developing energy systems for remote communities: Insights to best practices and sustainability. Sustain. Energy Technol. As. 2016, 16, 106-127.

6. Bhaskara, S.N.; Chowdhury, B.H. Microgrids-A review of modeling, control, protection, simulation and future potential. In Proceedings of the Power and Energy Society General Meeting, San Diego, CA, USA, 22-26 July 2012; pp. 1-7.

7. Venkatraman, R.; Khaitan, S.K. A survey of techniques for designing and managing microgrids. In Proceedings of the Power and Energy Society General Meeting, Denver, CO, USA, 26-30 July 2015; pp. 1-5.

8. Mitra, I.; Degner, T.; Braun, M. Distributed generation and microgrids for small island electrification in developing countries: A review. Sol. Energy Soc. India 2008, 18, 6-20.

9. Piagi, P.; Lasseter, R.H. Autonomous control of microgrids. In Proceedings of the Power Engineering Society General Meeting, Montreal, QC, Canada, 18-22 June 2006; pp. 1-8.

10. Salam, A.A.; Mohamed, A.; Hannan, M.A. Technical challenges on microgrids. ARPN J. Eng. Appl. Sci. 2008, 3, 64-69.

11. Tsikalakis, A.G.; Hatziargyriou, N.D. Centralized control for optimizing microgrids operation. IEEE Trans. Energy Convers. 2008, 23, 241-248.

12. Han, H.; Hou, X.; Yang, J.; Wu, J.; Su, M.; Guerrero, J.M. Review of power sharing control strategies for islanding operation of AC microgrids. IEEE Trans. Smart Grids 2016, 7, 200-215.

13. Schnitzer, D.; Lounsbury, D.S.; Carvallo, J.P.; Deshmukh, R.; Apt, J.; Kammen, D.M. Microgrids for Rural Electrification: A Critical Review of Best Practices Based on Seven Case Studies. In United Nations Found; 2014; pp. 1-122. Available online: http://energyaccess.org/wp-content/uploads/2015/07/ MicrogridsReportFINAL_high.pdf (accessed on 23 October 2017).

14. Patel, H.; Chowdhury, S. Review of technical and economic challenges for implementing rural microgrids in South Africa. In Proceedings of the IEEE PES PowerTech Conference, Eindhoven, The Netherlands, 29 June-2 July 2015; pp. 1-6.

15. Barnes, M.; Kondoh, J.; Asano, H.; Oyarzabal, J.; Ventakaramanan, G.; Lasseter, R.; Hatziargyriou, N.; Green, T. Real-world microgrids-An overview. In Proceedings of the IEEE International Conference on System of Systems Engineering, San Antonio, TX, USA, 16-18 April 2007; pp. 1-8.

16. Laaksonen, H.J. Protection principles for future microgrids. IEEE Trans. Power Electron. 2010, 25, $2910-2918$.

17. Moghaddam, M.J.H.; Bigdeli, M.; Miveh, M.R. A review of the primary-control techniques for the islanded microgrids. Elektrotehn. Vestnik 2015, 82, 169-175.

18. Akinyele, D.O.; Rayudu, R.K. Techno-economic and life cycle environmental performance analyses of a solar photovoltaic microgrid system for developing countries. Energy 2016, 109, 160-179.

19. Mohammed, Y.S.; Mustafa, M.W.; Bashir, N.; Mokhtar, A.S. Renewable energy resources for distributed power generation in Nigeria: A review of the potential. Renew. Sustain. Energy Rev. 2013, 22, 257-268.

20. Etxeberria, A.; Vechiu, I.; Camblong, H.; Vinassa, J.M. Hybrid energy storage systems for renewable energy sources integration in microgrids: A review. In Proceedings of the IPEC Conference, Singapore, 27-29 October 2010; pp. 532-537.

21. Zamora, R.; Srivastava, A.K. Controls for microgrids with storage: Review, challenges, and research needs. Renew. Sustain. Energy Rev. 2010, 14, 2009-2018.

22. Ravichandran, A.; Malysz, P.; Sirouspour, S.; Emadi, A. The critical role of microgrids in transition to a smarter grid: A technical review. In Proceedings of the IEEE Transportation Electrification Conference, Dearborn/Detroit, MI, USA, 16-19 June 2013. 
23. Parhizi, S.; Lotfi, H.; Khodaei, A.; Bahramirad, S. State of the art in research on microgrids: A review. IEEE Access 2015, 3, 890-925.

24. Stadler, M.; Cardoso, G.; Mashayekh, S.; Forget, T.; DeForest, N.; Agarwal, A.; Schönbein, A. Value streams in microgrids: A literature review. Appl. Energy 2016, 162, 980-989.

25. Gopalan, S.A.; Sreeram, V.; Iu, H.H.C. A review of coordination strategies and protection schemes for microgrids. Renew. Sustain. Energy Rev. 2014, 32, 222-228.

26. Han, Y.; Li, H.; Shen, P.; Coelho, E.A.A.; Guerrero, J.M. Review of active and reactive power sharing strategies in hierarchical controlled microgrids. IEEE Trans. Power Electron. 2017, 32, 2427-2451.

27. Unamuno, E.; Barrena, J.A. Hybrid AC/DC microgrids-Part I: Review and classification of topologies. Renew. Sustain. Energy Rev. 2015, 52, 1251-1259.

28. Planas, E.; Andreu, J.; Gárate, J.I.; Martínez de Alegría, I.; Ibarra, E. AC and DC technology in microgrids: A review. Renew. Sustain. Energy Rev. 2015, 43, 726-749.

29. Fathima, A.H.; Palanisamy, K. Optimization in microgrids with hybrid energy systems-A review. Renew. Sustain. Energy Rev. 2015, 45, 431-446.

30. Markvart, T. Microgrids. Refocus 2006, 7, 44-48.

31. Lasseter, R.H. MicroGrids. In Proceedings of the IEEE Power Engineering Society Winter Meeting Conference, New York, NY, USA, 27-31 January 2002; pp. 305-308.

32. Gaona, E.E.; Trujillo, C.L.; Guacaneme, J.A. Rural microgrids and its potential application in Colombia. Renew. Sustain. Energy Rev. 2015, 51, 125-137.

33. Fossati, J.P. Literature review of microgrids. Mem. Trab. Difusión Científica Y Técnica 2011, 9, 13-20.

34. Ustun, T.S.; Ozansoy, C.; Zayegh, A. Recent developments in microgrids and example cases around the world-A review. Renew. Sustain. Energy Rev. 2011, 15, 4030-4041.

35. Wang, X.; Guerrero, J.M.; Chen, F.B.Z. A review of power electronics based microgrids. J. Power Electron. 2012, 12, 181-192.

36. Miveh, M.R.; Rahmat, M.F.; Ghadimi, A.A.; Mustafa, M.W. Power quality improvement in autonomous microgrids using multi-functional voltage source inverters: A comprehensive review. J. Power Electron. 2015, 4, 1054-1065.

37. Majumder, R. Some aspects of stability in microgrids. IEEE Trans. Power Syst. 2013, 28, 3243-3252.

38. Akinyele, D. Analysis of photovoltaic mini-grid systems for remote locations: A techno-economic approach. Int. J. Energy Res. 2017, 1-18.

39. Miveh, M.R.; Gandomkar, M.; Mirsaeidi, S.; Gharibdoost, M.R. A review on protection challenges in Microgrids. In Proceedings of the Electrical Power Distribution Networks, Tehran, Iran, 2-3 May 2012; pp. 1-5.

40. Overseas Development Institute. Accelerating Access to Electricity in Africa with off-Grid Solar Country Briefing: Nigeria; Technical Report; Overseas Development Institute: London, UK, 2016.

41. Louie, H.; Dauenhauer, P.; Wilson, M.; Zomers, A.; Mutale, J. Eternal light: Ingredients for sustainable off-grid energy development. IEEE Power and Energy Mag. 2014, 12, 70-78.

42. El Bassam, N.; Maegaard, P.; Schlichting, M.L. Distributed Renewable Energies for Off-Grid Communities; Elsevier: Burlington, MA, USA, 2013.

43. Hong, G.W.; Abe, N. Sustainability assessment of renewable energy projects for off-grid rural electrification: The Pangan-an Island case in the Philippines. Renew. Sustain. Energy Rev. 2012, 16, 54-64.

44. Rosen, M.A. Energy sustainability: A pragmatic approach and illustrations. Sustainability 2009, 1, 55-80.

45. Rosen, M.A. Engineering sustainability: A technical approach to sustainability. Sustainability 2012, 4, 2270-2292.

46. Hossain, E.; Kabalci, E.; Bayindir, R.; Perez, R. Microgrid testbeds around the world: State of art. Energy Convers. Manag. 2014, 86, 132-153.

47. Khodaei, A. Provisional microgrids. IEEE Trans. Smart Grids 2015, 6, 1107-1115.

48. Chowdhury, S.; Chowdhury, S.P.; Crossley, P. Microgrids and Active Distribution Networks; IET: Stevenage, UK, 2009.

49. Lidula, N.W.A.; Rajapakse, A.D. Microgrids research: A review of experimental microgrids and test systems. Renew. Sustain. Energy Rev. 2011, 15, 186-202.

50. Eid, B.M.; Rahim, N.A.; Selvaraj, J.; El Khateb, A.H. Control methods and objectives for electronically coupled distributed energy resources in microgrids: A review. IEEE Syst. J. 2016, 10, 446-458. 
51. Jayasinghe, S.; Meegahapola, L.; Fernando, N.; Jin, Z.; Guerrero, J. Review of ship microgrids: System architectures, storage technologies and power quality aspects. Inventions 2017, 2, 4.

52. Emmanuel, M.; Akinyele, D.; Rayudu, R. Techno-economic analysis of a $10 \mathrm{kWp}$ utility interactive photovoltaic system at Maungaraki school, Wellington, New Zealand. Energy 2017, 120, 573-583.

53. Levron, Y.; Guerrero, J.M.; Beck, Y. Optimal power flow in microgrids with energy storage. IEEE Trans. Power Syst. 2013, 28, 3226-3234.

54. Poullikkas, A. Implementation of distributed generation technologies in isolated power systems. Renew. Sustain. Energy Rev. 2007, 11, 30-56.

55. Ackermann, T.; Andersson, G.; Söder, L. Distributed generation: a definition. Electr. Power Syst. Res. 2001, 57, 195-204.

56. Zomers, A. The challenge of rural electrification. Energy Sustain. Dev. 2003, 7, 69-76.

57. Foley, G. Rural electrification in the developing world. Energy Policy 1992, 20, 145-152.

58. Shyu, C.W. Rural electrification program with renewable energy sources: An analysis of China's Township Electrification Program. Energy Policy 2012, 51, 842-853.

59. Oyedepo, S.O. Towards achieving energy for sustainable development in Nigeria. Renew. Sustain. Energy Rev. 2014, 34, 255-272.

60. Oyedepo, S.O. On energy for sustainable development in Nigeria. Renew. Sustain. Energy Rev. 2012, 16, 2583-2598.

61. Midilli, A.; Dincer, I.; Ay, M. Green energy strategies for sustainable development. Energy Policy 2006, 34, 3623-3633.

62. Monstadt, J.; Wolff, A. Energy transition or incremental change? Green policy agendas and the adaptability of the urban energy regime in Los Angeles. Energy Policy 2015, 78, 213-224.

63. Zuo, J.; Zhao, Z.Y. Green building research-Current status and future agenda: A review. Renew. Sustain. Energy Rev. 2014, 30, 271-281.

64. Barry, M.L.; Steyn, H.; Brent, A. Selection of renewable energy technologies for Africa: Eight case studies in Rwanda, Tanzania and Malawi. Renew. Energy 2011, 36, 2845-2852.

65. Ozoegwu, C.G.; Mgbemene, C.A.; Ozor, P.A. The status of solar energy integration and policy in Nigeria. Renew. Sustain. Energy Rev. 2017, 70, 457-471.

66. Aliyu, A.K.; Modu, B.; Tan, C.W. A review of renewable energy development in Africa: A focus in South Africa, Egypt and Nigeria. Renew. Sustain. Energy Rev. 2018, 81, 2502-2518.

67. Shaaban, M.; Petinrin, J.O. Renewable energy potentials in Nigeria: Meeting rural energy needs. Renew. Sustain. Energy Rev. 2014, 29, 72-84.

68. Aliyu, A.S.; Dada, J.O.; Adam, I.K. Current status and future prospects of renewable energy in Nigeria. Renew. Sustain. Energy Rev. 2015, 48, 336-346.

69. Sambo, A.S. Strategic developments in renewable energy in Nigeria. Int. Assoc. Energy Econ. 2009, 4, 15-19.

70. Destouni, G.; Frank, H. Renewable energy. Renew. Energy 2010, 39, 18-21.

71. Charlier, R.H. Understanding renewable energy systems. Int. J. Environ. Stud. 2010, 67, 465-466.

72. Singh, G.K. Solar power generation by PV (photovoltaic) technology: A review. Energy 2013, 53, 1-13.

73. Makrides, G.; Zinsser, B.; Norton, M.; Georghiou, G.E.; Schubert, M.; Werner, J.H. Potential of photovoltaic systems in countries with high solar irradiation. Renew. Sustain. Energy Rev. 2010, 14, 754-762.

74. Akinyele, D.O; Rayudu, R.K. Comprehensive techno-economic and environmental impact study of a localised photovoltaic power system (PPS) for off-grid communities. Energy Convers. Manag. 2016, 124, 266-279.

75. Joshi, A.S.; Dincer, I.; Reddy, B.V. Performance analysis of photovoltaic systems: A review. Renew. Sustain. Energy Rev. 2009, 13, 1884-1897.

76. Akinyele, D.O.; Rayudu, R.K.; Nair, N.K.C. Global progress in photovoltaic technologies and the scenario of development of solar panel plant and module performance estimation-Application in Nigeria. Renew. Sustain. Energy Rev. 2015, 48, 112-139.

77. Luque, A.; Hegedus, S. Handbook of Photovoltaic Science and Engineering; Wiley: West Sussex, England, 2010.

78. McEvoy, A.; Markvart, T.; Castaner, L. Practical Handbook of Photovoltaics; Elsevier: Oxford, UK, 2012.

79. Boxwell, M. Solar Electricity Handbook-2015 Edition: A Simple, Practical Guide to Solar Energy-Designing and Installing Solar PV Systems; Greenstream Publishing: London, UK, 2015. 
80. Markvart, T.; Castañer, L. Practical Handbook of Photovoltaic: Fundamentals and Applications, 1st ed.; Elsevier: Oxford, UK, 2003.

81. IEEE Guide for Array and Battery Sizing in Stand-Alone Photovoltaic (PV) Systems; IEEE Std 1562-2007; USA, 2008. Available online: https:/ / standards.ieee.org/findstds/standard/1562-2007.html (accessed on 23 October 2017).

82. Akinyele, D.O.; Rayudu, R.K.; Tan, R.H.G. Comparative study of photovoltaic technologies based on performance, cost and space requirement: Strategy for selection and application. Int. J. Green Energy 2015, 13, 1352-1368.

83. Bhakta, S.; Mukherjee, V. Performance indices evaluation and techno economic analysis of photovoltaic power plant for the application of isolated India's island. Sustain. Energy Technol. As. 2017, 20, 9-24.

84. Chandel, M.; Agrawal, G.D.; Mathur, S.; Mathur, A. Techno-economic analysis of solar photovoltaic power plant for garment zone of Jaipur city. Case Stud. Therm. Eng. 2014, 2, 1-7.

85. Giwa, A.; Alabi, A.; Yusuf, A.; Olukan, T. A comprehensive review on biomass and solar energy for sustainable energy generation in Nigeria. Renew. Sustain. Energy Rev. 2017, 69, 620-641.

86. Paul, S.S.; Oyedepo, S.O.; Adaramola, M.S. Economic assessment of water pumping systems using wind energy conversion systems in the southern part of Nigeria. Energy Explor. Exploit. 2012, 30, 1-17.

87. Ajayi, O.O. Assessment of utilization of wind energy resources in Nigeria. Energy Policy 2009, 37, 750-753.

88. Fagbenle, R.O.; Katende, J.; Ajayi, O.O.; Okeniyi, J.O. Assessment of wind energy potential of two sites in North-East, Nigeria. Renew. Energy 2011, 36, 1277-1283.

89. Adekoya, L.O.; Adewale, A.A. Wind energy potential of Nigeria. Renew. Energy 1992, 2, 35-39.

90. Ojosu, J.O.; Salawu, R.I. A survey of wind energy potential in Nigeria. Sol. Wind Technol. 1990, 7, $155-167$.

91. Ajayi, O.O. The potential for wind energy in Nigeria. Wind Eng. 2010, 34, 303-311.

92. Ohunakin, O.S.; Akinnawonu, O.O. Assessment of wind energy potential and the economics of wind power generation in Jos, Plateau State, Nigeria. Energy Sustain. Dev. 2012, 16, 78-83.

93. Adaramola, M.S.; Oyewola, O.M. On wind speed pattern and energy potential in Nigeria. Energy Policy 2011, 39, 2501-2506.

94. Akinyele, D.O.; Rayudu, R.K.; Nair, N.K.C. Grid-independent renewable energy solutions for residential use: The case of an off-grid house in wellington, New Zealand. In Proceedings of the IEEE PES Asia-Pacific Power and Energy Engineering Conference, Brisbane, Australia, 15-18 November 2015; pp. 1-5.

95. Alnasir, Z.; Kazerani, M. An analytical literature review of stand-alone wind energy conversion systems from generator viewpoint. Renew. Sustain. Energy Rev. 2013, 28, 597-615.

96. Mansour, M.; Mansouri, M.N.; Mimouni, M.F. Performance evaluation of a flywheel energy-storage system associated to a variable-speed wind generator. In Sustainability in Energy and Buildings; Springer: Berlin, Heidelberg, 2012; pp. 201-211.

97. Samrat, N.H.; Ahmad, N.; Choudhury, I.A.; Taha, Z. Technical study of a standalone photovoltaic-Wind energy based hybrid power supply systems for island electrification in Malaysia. PLoS ONE 2015, 10, e0130678.

98. Burton, T.; Jenkins, N.; Sharpe, D.; Bossanyi, E. Wind Energy Handbook; Wiley: West Sussex, England, 2011.

99. Xu, L.; Ruan, X.; Mao, C.; Zhang, B.; Luo, Y. An improved optimal sizing method for wind-solar-battery hybrid power system. IEEE Trans. Sustain. Energy 2013, 4, 774-785.

100. Diaf, S.; Diaf, D.; Belhamel, M.; Haddadi, M.; Louche, A. A methodology for optimal sizing of autonomous hybrid PV/wind system. Energy Policy 2007, 35, 5708-5718.

101. Simonyan, K.; Fasina, O. Biomass resources and bioenergy potentials in Nigeria. Afr. J. Agr. Res. 2013, 8, 4975-4989.

102. Ericsson, N.; Nordberg, Å.; Sundberg, C.; Ahlgren, S.; Hansson, P.A. Climate impact and energy efficiency from electricity generation through anaerobic digestion or direct combustion of short rotation coppice willow. Appl. Energy 2014, 132, 86-98.

103. Holm-Nielsen, J.B.; Al Seadi, T.; Oleskowicz-Popiel, P. The future of anaerobic digestion and biogas utilization. Biores. Technol. 2009, 100, 5478-5484.

104. Demirbas, A.; Ozturk, T. Anaerobic digestion of agricultural solid residues. Int. J. Green Energy 2005, 1, 483-494.

105. Solid Biofuels-Determination of Calorific Value; ISO 18125:2017; International Organization for Standardization: Geneva, Switzerland, 2017. 
106. Günther, B.; Gebauer, K.; Barkowski, R.; Rosenthal, M.; Bues, C.T. Calorific value of selected wood species and wood products. Eur. J. Wood Wood Prod. 2012, 70, 755-757.

107. The Engineering Toolbox. Available online: https://www.engineeringtoolbox.com/fuels-higher-calorificvalues-d_169.html (accessed on 23 October 2017).

108. Diji, C.J. Electricity production from biomass in Nigeria: Options, prospects and challenges. Adv. Mat. Res. 2013, 824, 444-450.

109. Nwachukwu, C.C.; Lewis, C. A net energy analysis of fuels from biomass: The case of Nigeria. Biomass 1986, 11, 271-289.

110. Sokan-Adeaga, A.A.; Ana, G.R.E.E. A comprehensive review of biomass resources and biofuel production in Nigeria: potential and prospects. Rev. Environ. Health 2015, 30, 143-162.

111. Abila, N. Biofuels development and adoption in Nigeria: Synthesis of drivers, incentives and enablers. Energy Policy 2012, 43, 387-395.

112. Amigun, B.; Musango, J.K.; Stafford, W. Biofuels and sustainability in Africa. Renew. Sustain. Energy Rev. 2011, 15, 1360-1372.

113. Akinyele, D.O.; Rayudu, R.K. Review of energy storage technologies for sustainable power networks. Sust. Energy Technol. As. 2014, 8, 74-91.

114. Ohunakin, O.S.; Ojolo, S.J.; Ajayi, O.O. Small hydropower (SHP) development in Nigeria: An assessment. Renew. Sustain. Energy Rev. 2011, 15, 2006-2013.

115. Okpanefe, P.E.; Owolabi, S. Small hydropower in Nigeria. SHP News 2002, 19, $2-4$.

116. European Small Hydropower Association. Guide on How to Develop a Small Hydropower Plant; Technical Report; European Small Hydropower Association: Brussels, Belgium, 2004.

117. Okot, D.K. Review of small hydropower technology. Renew. Sustain. Energy Rev. 2013, 26, 515-520.

118. Balat, H. A renewable perspective for sustainable energy development in Turkey: The case of small hydropower plants. Renew. Sustain. Energy Rev. 2007, 11, 2152-2165.

119. Akuru, U.B.; Onukwube, I.E.; Okoro, O.I.; Obe, E.S. Towards 100\% renewable energy in Nigeria. Renew. Sustain. Energy Rev. 2017, 71, 943-953.

120. Akinyele, D.O.; Rayudu, R.K. Distributed photovoltaic power generation for energy-poor households: The Nigerian perspective. In Proceedings of the IEEE PES Asia-Pacific Power and Energy Engineering Conference, Kowloon, Hong Kong, China, 8-11 December 2013.

121. U.S. Energy Information Administration. Nigeria: Country Analysis Brief Overview; Technical Report; Independent Statistics \& Analysis; U.S. Energy Information Administration: Washington, DC, USA, 2016.

122. Premium Times. Available online: www.premiumtimesng.com/news/more-news/240258-nigeriascurrent-electricity-generating-capacity-6803-mw-fashola.html (accessed on 23 January 2018).

123. Aliyu, A.S.; Ramli, A.T.; Saleh, M.A. Nigeria electricity crisis: Power generation capacity expansion and environmental ramifications. Energy 2013, 61, 354-367.

124. Ohunakin, O.S.; Adaramola, M.S.; Oyewola, O.M.; Fagbenle, R.O. Solar energy applications and development in Nigeria: Drivers and barriers. Renew. Sustain. Energy Rev. 2014, 32, 294-301.

125. Okoye, C.O.; Taylan, O.; Baker, D.K. Solar energy potentials in strategically located cities in Nigeria: Review, resource assessment and PV system design. Renew. Sustain. Energy Rev. 2016, 55, 550-566.

126. Oseni, M.O. Improving households' access to electricity and energy consumption pattern in Nigeria: Renewable energy alternative. Renew. Sustain. Energy Rev. 2012, 16, 3967-3974.

127. Emodi, N.V.; Yusuf, S.D. Improving electricity access in Nigeria: Obstacles and the way forward. Int. J. Energy Econ. Policy 2015, 5, 335-351.

128. Mas'ud, A.A.; Wirba, A.V.; Muhammad-Sukki, F.; Mas'ud, I.A.; Munir, A.B.; Yunus, N.M. An assessment of renewable energy readiness in Africa: Case study of Nigeria and Cameroon. Renew. Sustain. Energy Rev. 2015, 51, 775-784.

129. Adeoti, O.; Oyewole, B.A.; Adegboyega, T.D. Solar photovoltaic-based home electrification system for rural development in Nigeria: Domestic load assessment. Renew. Energy 2001, 24, 155-161.

130. Gollwitzer, L. Community-Based Micro Grids: A Common Property Resource Problem; Technical Report; STEPS Centre: Brighton, UK, 2014.

131. Adeleke, A.A. Sustainability of solar mini-grids in Nigeria. Master's Thesis, University of Ibadan, Ibadan, Nigeria, 2016. 
132. Newsom, C. Renewable Energy Potential in Nigeria; Technical Report G03512; International Institute for Environment and Development: London, UK, 2012.

133. Onasanya, M.A. An evaluation and development of the potentials of photovoltaic systems for water pumping and electricity services in rural areas of Nigeria. Ph.D. Thesis, Institute of Energy and Sustainable Development de Montfort University, Leicester, UK, 2017.

134. Julius, E.; Olufemi, A.O.; Chuks, D.J. Challenges of sustaining off-grid power generation in Nigeria rural communities. Afr. J. Eng. Res. 2014, 2, 51-57.

135. Ikeme, J.; Ebohon, O.J. Nigeria's electric power sector reform: what should form the key objectives? Energy Policy 2005, 33, 1213-1221.

136. Lawhon, M.; Murphy, J.T. Socio-technical regimes and sustainability transitions. Prog. Hum. Geog. 2011, 36, 354-378.

137. Pereira, T. Sustainability: An integral engineering design approach. Renew. Sustain. Energy Rev. 2009, 13, 1133-1137.

138. Aydin, B. SWOT analysis of renewable energy. In Proceedings of the International Conference and Utility Exhibition on Green Energy for Sustainable Development, Pattaya City, Thailand, 19-21 March 2014; pp. 1-7.

139. Jaber, J.O.; Elkarmi, F.; Alasis, E.; Kostas, A. Employment of renewable energy in Jordan: Current status, SWOT and problem analysis. Renew. Sustain. Energy Rev. 2015, 49, 490-499.

140. Terrados, J.; Almonacid, G.; Hontoria, L. Regional energy planning through SWOT analysis and strategic planning tools. Renew. Sustain. Energy Rev. 2007, 11, 1275-1287.

141. Chen, W.M.; Kim, H.; Yamaguchi, H. Renewable energy in eastern Asia: Renewable energy policy review and comparative SWOT analysis for promoting renewable energy in Japan, South Korea, and Taiwan. Energy Policy 2014, 74, 319-329.

142. Krupa, J.; Burch, S. A new energy future for South Africa: The political ecology of South African renewable energy. Energy Policy 2011, 39, 6254-6261.

143. Akinyele, D.O.; Nair, N.K.C.; Rayudu, R.K.; Seah, W.K.G. Clean development mechanism projects for developing countries: Potential for carbon emissions mitigation and sustainable development. In Proceedings of the 18th National Power Systems Conference, Guwahati, India, 18-20 December 2014.

144. Emodi, N.V.; Boo, K.J. Sustainable energy development in Nigeria: Current status and policy options. Renew. Sustain. Energy Rev. 2015, 51, 356-381.

145. Zalengera, C; Blanchard, R.E.; Eames, P.C.; Juma, A.M.; Chitawo, M.L.; Gondwe, K.T. Overview of the Malawi energy situation and A PESTLE analysis for sustainable development of renewable energy. Renew. Sustain. Energy Rev. 2014, 38, 335-347.

146. Kumar, A.; Mohanty, P.; Palit, D.; Chaurey, A. Approach for standardization of off-grid electrification projects. Renew. Sustain. Energy Rev. 2009, 13, 1946-1956.

147. Zerriffi, H. Rural Electrification; Springer: Dordrecht, The Netherlands, 2011.

148. Chen, S.; Liu, T.; Gao, F.; Ji, J.; Xu, Z.; Qian, B.; Wu, H.; Guan, X. Butler, not servant: A human-centric smart home energy management system. IEEE Commun. Mag. 2017, 55, 27-33.

149. Seifi, M.; Soh, A.C.; Wahab, N.I.A.; Hassan, M.K. Modeling of PV standalone microgrid based on IEEE standards, 1562-2007, 1361-2003 and 1013-2007. Rev. Model. Simul. 2013, 6, 515-525.

150. IEEE Guide for Selecting, Charging, Testing, and Evaluating Lead-Acid Batteries Used in Stand-Alone Photovoltaic (PV) Systems; IEEE Std 1361-2014; IEEE: New York, NY, USA, 2014; ISBN 978-0-7381-9172-0.

151. Arndt, R.; Puto, R. Basic Understanding of IEC Standard Testing for Photovoltaic Panels; Technical Report; TÜV SÜD America Inc.: Peabody, MA, USA, 2010.

152. Morgan, R.K. Environmental impact assessment: the state of the art. Impact Assess. Proj. A 2012, 30, 5-14.

153. Schwaegerl, C.; Tao, L.; Lopes, J.P.; Madureira, A.; Mancarella, P.; Anastasiadis, A.; Hatziargyriou, N.; Krkoleva, A. Report on the technical, social, economic, and environmental benefits provided by Microgrids on power system operation. In Advanced Architectures and Control Concepts for More Microgrids; More MicroGrids EU-Project; 2009. Available online: http://www.microgrids.eu/documents/668.pdf (accessed on 23 January 2018).

154. Ajayi, O.O.; Ajayi, O.O. Nigeria's energy policy: Inferences, analysis and legal ethics toward RE development. Energy Policy 2013, 60, 61-67. 
155. Feron, S. Sustainability of off-grid photovoltaic systems for rural electrification in developing countries: A review. Sustainability 2016, 8, 1326 .

156. Yue, D.; You, F.; Darling, S.B. Domestic and overseas manufacturing scenarios of silicon-based photovoltaics: Life cycle energy and environmental comparative analysis. Sol. Energy 2014, 105, 669-678.

157. Bhattacharyya, S. Rural Electrification Through Decentralised Off-Grid Systems in Developing Countries; Springer: London, UK, 2013.

158. Bourgeois, T.; Gerow, J.; Litz, F.; Martin, N. Community Microgrids: Smarter, Cleaner; Technical Report; Pace Energy \& Climate Center: New York, NY, USA, 2013.

159. Microgrid Knowledge. Community Microgrids: A Guide for Mayors and City Leaders Seeking Clean, Reliable and Locally Controlled Energy; Technical Report; Microgrid Knowledge: Westborough, MA, USA, 2015.

160. Baxter, K.; Courage, C. Understanding Your Users: A practical Guide to User Research Methods; Morgan Kaufmann: San Fancisco, CA, USA, 2005.

161. Electricity Information Sharing and Analysis Center. Available online: https://ics.sans.org/media/EISAC_SANS_Ukraine_DUC_5.pdf (accessed on 23 January 2018).

162. Akinyele, D.; Belikov, J.; Levron, Y. Battery storage technologies for electrical applications: Impact in stand-alone photovoltaic systems. Energies 2017, 10, 1760.

163. Hung, C. Environmental impacts of renewable energy: A overview of life-cycle results. Master's Thesis, Norwegian University of Science and Technology (NTNU), Trondheim, Norway, 2010.

164. Hall, C.A.S.; Lambert, J.G.; Balogh, S.B. EROI of different fuels and the implications for society. Energy Policy 2014, 64, 141-152.

165. Singh, A.; Olsen, S.I.; Pant, D. Life Cycle Assessment of Renewable Energy Sources; Springer: London, UK, 2013.

166. Theodorou, S.; Florides, G.; Tassou, S. The use of multiple criteria decision making methodologies for the promotion of RES through funding schemes in Cyprus, A review. Energy Policy 2010, 38, 7783-7792.

167. Ahmad, S.; Tahar, R.M. Selection of renewable energy sources for sustainable development of electricity generation system using analytic hierarchy process: A case of Malaysia. Renew. Energy 2014, 63, 458-466.

168. Schillebeeckx, S.J.D.; Parikh, P.; Bansal, R.; George, G. An integrated framework for rural electrification: Adopting a user-centric approach to business model development. Energy Policy 2012, 48, 687-697.

169. Soshinskaya, M.; Crijns-Graus, W.H.J.; Guerrero, J.M.; Vasquez, J.C. Microgrids: Experiences, barriers and success factors. Renew. Sustain. Energy Rev. 2014, 40, 659-672.

170. Chaurey, A.; Kandpal, T.C. A techno-economic comparison of rural electrification based on solar home systems and PV microgrids. Energy Policy 2010, 38, 3118-3129.

171. Jha, S.K.; Stoa, P.; Uhlen, K. Microgrid: Prospects and challenges in Nepal. In Proceedings of the Power and Energy Systems Conference: Towards Sustainable Energy, Bangalore, India, 13-15 March 2014. 